\title{
Imperfect Competition in the Interbank Market for Liquidity as a Rationale for Central Banking *
}

\author{
Viral V. Acharya \\ London Business School \\ New York University \\ CEPR and NBER
}

\author{
Denis Gromb \\ INSEAD \\ and $C E P R$
}

\author{
Tanju Yorulmazer \\ Federal Reserve Bank of New York
}

First draft: May 2007

This draft: October 23, 2009

\footnotetext{
*Contact: Viral Acharya, Department of Finance, Stern School of Business, New York University, 44 West 4th Street, Room 9-84, New York, NY 10012, US. Tel: +1 2129980354 Fax: +1 2129954256 e-mail: vacharya@stern.nyu.edu. We are grateful to Franklin Allen, Arnoud Boot, Enrica Detragiache, Darrell Duffie, Douglas Gale, Charles Goodhart, Enisse Kharroubi, Alan Morrison, Leonard Nakamura, Henri Pagès, Loriana Pelizzon, Raghuram Rajan, Adriano Rampini, Stacey Schreft, Peter Sinclair, Hyun Shin, Ellis Tallman, Anjan Thakor, Vikrant Vig, Goetz von Peter, Lucy White, Matthew Willison, and seminar participants at Bank of England, Bank of Portugal, the BCBS-CEPR-JFI "Risk Transfer Mechanisms and Financial Stability" Workshop, the CEPR conference on Banking and the Macroeconomy at ETH Zurich, CREST, University of Chicago, ESSEC, Essex University, INSEAD, Lancaster, London Business School, London School of Economics, Queen's University, the Second New York Fed-Princeton Liquidity Conference, the Federal Reserve Banks of Cleveland, New York and Philadelphia, the Swiss Winter Finance Conference in Champery, and the Université Paris Dauphine for helpful suggestions. All errors remain our own. Part of this paper was completed while Viral Acharya was visiting Stanford-GSB. The views expressed here are those of the authors and do not necessarily represent the views of the Federal Reserve Bank of New York or the Federal Reserve System.
} 


\title{
Imperfect Competition in the Interbank Market for Liquidity as a Rationale for Central Banking
}

\begin{abstract}
We study liquidity transfers between banks through the interbank borrowing and asset sale markets when (i) surplus banks providing liquidity have market power, (ii) there are frictions in the lending market due to moral hazard, and (iii) assets are bank-specific. We show that when the outside options of needy banks are weak, surplus banks may strategically under-provide lending, thereby inducing inefficient sales of bank-specific assets. A central bank can ameliorate this inefficiency by standing ready to lend to needy banks, provided it has greater information about banks (e.g., through supervision) compared to outside markets, or is prepared to extend potentially loss-making loans. The public provision of liquidity to banks, in fact its mere credibility, can thus improve the private allocation of liquidity among banks. This rationale for central banking finds support in historical episodes preceding the modern era of central banking and has implications for recent debates on the supervisory and lender-of-last-resort roles of central banks.
\end{abstract}

JEL classification: G21, G28, G38, E58, D62.

Keywords: Competition, Interbank lending, Market power, Asset specificity, Central bank, Lender of last resort. 


\section{Introduction}

The liquidity squeeze during the ongoing crisis of 2007-09 has been likened by some observers, including the IMF, to the financial sector turmoil of the Depression era. A nagging problem faced by central banks during the early part of this crisis was the difficulty in getting open-market operations, discount window and securities lending to channel liquidity to the most needy parts of the financial system. Some of the lending facilities such as the discount window were not availed by players, and others when availed merely resulted in hoarding of liquidity by banks and other institutions. For example, Acharya and Merrouche (2009) document, for example, that the U.K. banks' liquidity buffers experienced an almost permanent upward shift of 30\% in August 2007 (relative to their pre-August levels) and the result was a rise in borrowing costs between banks and an almost complete drying up of liquidity in interbank markets beyond the very short maturities. ${ }^{1}$ In response, central banks around the world, most notably the Federal Reserve, undertook significant changes to their lender-of-last-resort facilities, in particular, by extending maturities of discount window and open-market operations, extending eligible collateral to include investment-grade debt securities, and making such adjustments for lending to primary dealers as well.

The episode begs several important questions: Why have the interbank markets, which in normal times act as lubricant to financial flows amongst banks, dried up so suddenly? Why have the traditional forms of central bank's lender-of-last-resort facilities failed to allocate liquidity to places needing it most? Indeed, going forward, how should central banks provide these facilities for them to be effective during crises? Do limits to the precision of supervisory information about banks compromise central banks' effectiveness in overcoming the failure of interbank markets? Our paper attempts to provide a theoretical answer some of these questions based on a specific market failure stemming from market power in liquidity transfers between banks.

We propose that during crises, efficient liquidity transfers may not occur between surplus and liquidity stricken banks. We analyze one such source of inefficiency arising from the market power of surplus banks in the market for interbank liquidity transfers and the strategic gains they derive from buying assets from liquidity stricken banks at fire sale prices and, more generally, gaining market share at their expense. We determine conditions under which a central bank can mitigate this inefficiency by standing ready to lend to needy banks. We report historical episodes in support of this rationale for central banking and discuss implications for recent debates on the supervisory and lender-of-lastresort functions.

We consider liquidity transfers between a surplus and a needy bank through two markets: the interbank market and the asset sales market. Our model has three main ingredients. First, we assume that some assets are bank-specific, i.e., they are worth more under current than under alternative ownership. For instance, alternative owners may lack current owner's expertise. For this reason, asset sales are less attractive than borrowing (from a first-best standpoint). Second, we assume frictions in the interbank

\footnotetext{
${ }^{1}$ Source: "Hoarding by banks stokes fears over crisis: Borrowing costs rise between institutions; (Central Bank) Efforts on lending fail to bear fruit," Financial Times, 3/26/2008.
} 
lending market, which we model as arising from a moral hazard problem. Specifically, we assume that banks can monitor their assets to improve their performance, and that monitoring is costly. A bank borrowing in the interbank market must retain a large enough claim on its own assets to have incentives to monitor them. This friction limits banks' borrowing capacity so that in the second-best, banks are forced to engage in asset sales when borrowing needs are sufficiently high. Third, we assume that during crises, liquidity is concentrated within a few banks, giving them market power. It is this last assumption, and its interaction with other two, that drive the core of our analysis.

We show that the market power of surplus banks can lead to more asset sales, and importantly, more inefficient asset sales by banks in need of liquidity. The intuition is that banks with market power in the interbank market can extract rents from banks seeking liquidity. Given the moral hazard problem, needy bank's borrowing capacity is limited and it must engage in more asset sales to the surplus bank. Effectively, the surplus bank can extract rents either by charging higher interest rate or alternatively by paying less for the assets. The higher the surplus bank's market power, the worse the inefficiency arising from excessive asset sales.

The surplus bank's ability to exploit market power is limited by the outside option provided by the market, for example, raising liquidity through commercial paper issuance or raising public debt. Therefore, the problem of inefficient asset sales is more acute the weaker is the outside market, a scenario that would arise, for instance, in liquidation of opaque or information-sensitive assets and bank-specific loans made to small borrowers.

The key insight from these results is that due to market power, even states without aggregate shortage of liquidity are effectively converted into states of aggregate liquidity shortage. $^{2}$ We argue that this implies a rationale for the lender-of-last-resort role of a central bank. A central bank that is credible in providing liquidity to needy banks curbs the market power of surplus banks in the interbank lending market and thus improves the efficiency of liquidity transfers. In particular, the central bank can play a "virtual and virtuous" role: In our model, it never actually lends to needy banks in equilibrium, but merely improves their bargaining position vis-à-vis surplus banks. We show however that such an improvement requires the central bank to be better than outside markets at extending loans to needy banks or be ready to incur potential losses. The former situation is more likely if the central bank also has a supervisory role, allowing it to improve its ability to monitor its lending to liquidity stricken banks. In particular, the role for ex-ante investments in supervision does not arise as a way to reduce the incidence of central bank making loans ex post, but to make such intervention credible and thereby improve the private allocation of liquidity among banks.

We also study the possibility for banks to insure against liquidity shocks. This possi-

\footnotetext{
${ }^{2}$ This may even cause liquidity stricken banks to fail. Outside of our model, this may even lead to contagion on other banks which look similar to liquidity stricken banks. For example, Goodhart (1969) discusses the role of such a contagion effect during the 1907 crisis. On October 21, the National Bank of Commerce refused to clear for the Knickerbocker Trust Company, which precipitated a run on Knickerbocker. One suggestion is that this move was part of severe competition and a fight for market share between national banks and trust companies in New York and National Bank of Commerce took the opportunity to eliminate a rival or a set of rivals since the run on Knickerbocker spilled over onto all other trust companies.
} 
bility reduces the inefficiency in interbank liquidity transfers. However, as long as banks can only get partial liquidity insurance, surplus banks' ex post market power increases (or creates) inefficiency in the allocation of liquidity. This leads to several additional results. First, if banks that are likely to have excess liquidity and market power ex post are also the best liquidity insurers ex ante, their market power reduces the scope for liquidity insurance. Put simply, committing to provide liquidity insurance conflicts with incentives to retain and exploit market power. Second, committing to provide liquidity insurance is costly for banks as they may potentially require liquidity in future too. Thus, if states with aggregate shortage of liquidity are more likely, then it is more costly for banks to provide liquidity insurance, resulting in lower levels of ex-ante insurance. This, in turn, increases the ex-post market power of liquidity rich banks even in states without any aggregate liquidity shortage.

These results imply that ex-ante provision of liquidity insurance is likely to be incomplete, as observed in practice, and market power considerations arise in a robust manner when liquidity distribution across banks is highly skewed. ${ }^{3}$

To summarize, our model illustrates that the public provision of liquidity, in fact, its mere credibility, can improve its private provision even in times of aggregate liquidity surplus. This lender-of-last-resort rationale for the existence of a central bank complements the traditional one pertaining to times of aggregate liquidity shortages and contagious failures (e.g., Allen and Gale (1998), Holmström and Tirole (1998), Diamond and Rajan (2005), Gorton and Huang (2006)). Our analysis also clarifies why central banks should assume both roles of supervisor and lender-of-last-resort.

We provide historical and current accounts from various countries that support the notion of market power of cash-rich banks during crises in Appendix B. In particular, we present evidence on: (i) failure of private coinsurance arrangements such as the Clearinghouse System first established by the New York City banks in 1853; (ii) the role of J.P. Morgan and National City Bank, which was to become Citibank, in the 1907 crisis and how they benefited using market power during the crisis; (iii) the emergence of modern central banking as public institution concerned with the overall financial stability of the system rather than as a competitor to other banks as was the case in early era of central banking; (iv) the role of central banks in stabilizing markets and interest rates during crises from Donaldson (1992) that compares interest rates during the pre-Fed (1867-1913) and post-Fed (1914-1933) periods to show that the establishment of the Federal Reserve to act as a lender of last resort during panic periods prevented surplus banks from exerting market power; and (v) market power in non-bank parts of the financial system such as the episodes of failure of LTCM in 1998 and Amaranth in 2006.

Our model, while not reflecting all aspects of inter-bank markets, is aimed at captur-

\footnotetext{
${ }^{3}$ Other reasons for liquidity insurance to be only partial include the impossibility to enter binding long-term contracts, the fragility of implicit contracts in crises situations, or the possibility of aggregate liquidity shortage combined with liquid banks' cost of capital being non-verifiable. For instance, banks could enter implicit contracts for liquidity provision, sustained through reputation and repeated interactions. This may however also be less relevant during crises. Indeed, Carlin, Lobo and Viswanathan (2007) show that such contracts break down when the "prey" is large or close to default since the continuation of a relationship is less valuable. Crises may represent exactly such situations.
} 
ing the market power issues arising due to "tiering" and relationships, even present in today's over-the-counter interbank markets. It is our understanding that even in large interbank markets such as those in the US and the UK, issues of market power and concentration remain important. For example, in the US, the Fed Funds market is a tiered and concentrated market, where two banks, JPMC and Bank of America, are very big borrowers with a huge difference in volume from the rest of the banks, and two banks, State Street and JPMC, are big lenders, again with a huge difference in volume from the rest. Furthermore, a significant proportion of banks have connections with only one or two banks, where the average number of connections is only somewhere between three and four, which is low when we take into account of the fact that only a few banks are involved in most of inter-bank connections (see Bech and Atalay (2008)). The UK too has a tiered banking system and the volatility induced in inter-bank lending rates due to cornering of collateral and liquidity by some of the large settlement banks during 2001-2005 was one of the primary rationales for the Money Market Reform in 2006. Post-Reform, the Bank of England allowed more banks in open market operations increasing the number from 10 to more than 35 (see Bank of England (2005) and Tucker (2004)). Finally, Cocco et. al. (2005) provide evidence supportive of strong inter-bank relationships in the Portuguese inter-bank market. This microstructure suggests that outcomes in interbank markets are unlikely to be of the competitive type, especially during crises when distribution of liquidity tends to be asymmetric and concentrated in hands of few players.

Related literature Our paper is related to the literature on the failure of interbank markets that justifies the lender-of-last-resort role of central banks. ${ }^{4}$ Goodfriend and King (1988) argue that with efficient interbank markets, central banks should not lend to individual banks but instead provide sufficient liquidity via open market operations, which the interbank market would then allocate efficiently among banks. Others however, argue that interbank markets may fail to allocate liquidity efficiently due to frictions such as asymmetric information about banks' assets (Flannery (1996), Freixas and Jorge (2007)), banks' free-riding on each other's liquidity (Bhattacharya and Gale (1987)), or on the central bank's liquidity (Repullo (2005)). Instead, our paper focuses on the (additional) frictions brought about by market power. ${ }^{5}$

Donaldson (1992) is, to our knowledge, the only paper with a similar focus. Using Dunn and Spatt (1984)'s strategic pricing model, it shows that even if aggregate liquidity is in surplus, if some banks have a significant proportion of the excess cash so that other cash rich banks' resources are not enough to satisfy the total liquidity demand, banks can exploit this captive demand and charge higher than competitive rates.

\footnotetext{
${ }^{4}$ Indirectly, therefore, our model is also related to the literature justifying the existence of interbank markets in the first place, specifically their role in allowing banks to insure each other against liquidity shocks through borrowing and lending facilities (e.g. Rochet and Tirole (1996), Allen and Gale (2000)).

${ }^{5}$ Appendix B reports historical evidence of such cash hoarding. Casual empiricism suggests that such cases are not uncommon in recent times either. Our private communications with bankers suggest that one of the perceived reasons for interbank markets drying up during the recent sub-prime crisis of 2007-09 was the hoarding of liquidity by banks for acquisitions of troubled institutions at fire-sale prices, the other two reasons being a precautionary motive from the risk of being distressed and asymmetric information about borrowing institutions.
} 
While some theory papers study the reallocation of funds (e.g. Holmström and Tirole (1998)) and others that of assets (e.g. Shleifer and Vishny (1992), Gorton and Huang (2002)), ours studies both and illustrates the trade-offs involved. We believe banks' dual role as each other's financiers and business competitors to be an important and specific aspect of their relationships. ${ }^{6}$

Our paper is also related to the literature on predation, i.e., when rivals take actions that weakens a firm's access to finance (Bolton and Scharfstein (1990), Cestone (2000)). Here, however, the dual relationship between banks means that the predator is also the prey's financier.

The paper proceeds as follows. Section 2 presents the model. Section 3 presents its analysis. Section 4 discusses the effect of the banks' loan portfolio characteristics. Section 5 presents the rationale for central banking. Section 6 deals with liquidity insurance and its limits. Section 7 discusses robustness issues and Section 8 presents policy implications. Section 9 concludes. Proofs and a detailed discussion of historical evidence in support of market power in inter-bank markets and other settings with financial institutions are in the Appendix.

\section{The model}

Consider a model with three dates $t=0,1,2$, two banks, Bank $A$ and Bank $B$, universal risk neutrality and no discounting. ${ }^{7}$ The timeline of the model is illustrated in Figure 1.

At $t=0$, Bank $A$ has a continuum of measure 1 of risky assets, e.g., loans to the corporate sector. At $t=2$, each loan yields a random return $\widetilde{R} \in\{0, R\}$ which depends on whether the loan was monitored and on an unobservable state of nature $\omega$ uniformly distributed over $[0,1]$.

At $t=1$, each loan needs some refinancing of $\rho$ units of cash, e.g., rolling over of an existing loan or a drawdown on a line of credit. ${ }^{8}$ If a loan is not refinanced, $\widetilde{R}=0$. If it is refinanced, $\widetilde{R}=R$ if $\omega \in[0, p]$ and $\widetilde{R}=0$ otherwise. The bank can affect the probability $p$ by monitoring its loans at $t=1: p=p_{H}$ if it monitors, and $p=p_{L}=\left(p_{H}-\Delta p\right)$ otherwise, with $\Delta p>0$. Monitoring is non-verifiable and the bank enjoys a private benefit $b$ per

\footnotetext{
${ }^{6}$ While Bear Stearns is formally not a bank, its sale to J.P.Morgan Chase, in March 2008, illustrates well the confluence of (J.P.Morgan Chase's) roles as lender and asset purchaser. During the liquidity crisis at Bear Stearns and its subsequent resolution, J.P.Morgan Chase explicitly stated its strong interest in Bear Stearns' prime brokerage business. While there were systemic-risk concerns about Bear Stearns' possible collapse, which are outside the scope of current paper, it is interesting to note that J.P.Morgan Chase does seem to have made the acquisition at a fire-sale price: On 3/13/2008, Bear Stearns' stock price was $\$ 57$, J.P.Morgan Chase agreed to acquire Bear Stearns on 3/17/2008 at $\$ 6$ a share with a guarantee of $\$ 30$ billion from the Fed to fund Bear's less liquid assets such as mortgage-backs; J.P.Morgan Chase's stock went up $10 \%$ on $3 / 17 / 2008$, whereas most other financial stocks lost value; finally, the deal was revised and J.P.Morgan Chase agreed to increase the purchase price to $\$ 10$ a share and to bear the first $\$ 1$ billion of loss that may arise from the loan provided by the Fed.

${ }^{7}$ The model builds on Holmström and Tirole (1998).

${ }^{8}$ Alternatively, in a model with liability structure of banks, the liquidity need could stem from depositor withdrawals or the bank's inability to rollover unsecured funding such as short-term commercial paper.
} 
loan it does not monitor. If the loan is not refinanced, the bank derives no private benefit either. We assume it is efficient to refinance a loan only if it is monitored, i.e.,

$$
p_{H} R>\rho>p_{L} R+b .
$$

We assume Bank $B$ has enough excess liquidity to refinance Bank $A$ 's loans. This assumes implicitly that banks that form interbank lending relationships have imperfectly correlated liquidity shocks. ${ }^{9}$

The liquidity transfer can occur in two ways: Bank $A$ can borrow from Bank $B$ or sell it some of its loans.

Borrowing: Due to limited liability, moral hazard in monitoring limits Bank $A$ 's borrowing capacity. Indeed, an interbank loan is a transfer $L$ from Bank $B$ to Bank $A$ against a repayment $r$ if $\widetilde{R}=R$ and 0 if $\widetilde{R}=0 .{ }^{10}$ Bank $A$ chooses to monitor its loans only if:

$$
\Delta p(R-r) \geq b \text {. }
$$

For this incentive compatibility constraint to hold, the repayment $r$ must be small enough, i.e.,

$$
r \leq\left(R-R_{b}\right) \text { with } R_{b} \equiv b / \Delta p .
$$

Bank A's borrowing capacity conditional on monitoring, i.e., the maximum funding it can raise against each loan while retaining monitoring incentives is therefore

$$
p_{H}\left(R-R_{b}\right) \text {. }
$$

Asset sales: Each loan can be sold to Bank $B$ at a price $P$. We assume Bank $A$ to be the most efficient user of its assets, i.e., they are Bank $A$-specific. This may stem from expertise or learning-by-doing effects for making and administering loans or from customer relationships. ${ }^{11}$ Moreover, Bank $A$ 's advantage over Bank $B$ may vary across loans. For instance, smaller loans, or loans relying more on Bank $A$ 's relationship with the borrower may be more difficult for Bank $B$ to take over. The relevant loan characteristic is captured by a variable $\theta$ distributed over $[0,1]$ according to the cumulative distribution function (c.d.f.) $F$. Loans with smaller values of $\theta$ are less redeployable to Bank $B$. Nevertheless, we assume it is efficient to refinance loans even if owned by Bank $B$. If Bank $B$ owns a loan of Bank $A$ with characteristic $\theta$, then $p=p_{B}(\theta)$ with

$$
p_{H}>p_{B}(\theta)>\rho / R \text { and }\left(\frac{d p_{B}(\theta)}{d \theta}\right)>0 .
$$

\footnotetext{
${ }^{9}$ Cocco et.al. (2005) provide supporting evidence that (Portuguese) banks with more volatile liquidity shocks rely more on lending relationships and borrow from banks with less volatile and less correlated liquidity shocks.

${ }^{10}$ Note that with two possible cash flows, one being zero, the distinction between debt and equity is immaterial.

${ }^{11}$ If banks forming interbank lending relationships are in different businesses or have relationship, information-sensitive loans this assumption is natural. Empirically, Dell'Arricia, Detragiache and Rajan (2008) and Krozner, Laeven and Klingebiel (2007) show that financially dependent sectors perform relatively worse during banking crises, which is consistent with the importance of bank relationships and information-sensitive loans.
} 
With bank-specific assets, asset sales are less efficient than borrowing, conditional on monitoring. ${ }^{12}$ However, we assume that moral hazard in monitoring is severe enough (i.e., $b$ large) so that Bank $A$ can raise more funds by selling a loan than by pledging some of its return. Our results are largely unchanged if $p_{B}(\theta) R>\rho$ and $p_{B}(\theta) R>p_{H}\left(R-R_{b}\right)$ held only for some loans.

Assumption 1 For all $\theta \in[0,1], p_{B}(\theta) R>p_{H}\left(R-R_{b}\right)$.

We model the banks' interaction in the interbank lending and the asset markets as a two-stage bargaining game of alternating offers with risk of breakdown. ${ }^{13}$ The game tree for the bargaining game is illustrated in Figure 2. First, Bank $B$ makes Bank $A$ an offer with three components: A subset of measure $\alpha$ of Bank $A$ 's assets to be acquired by Bank $B$, a repayment $r \leq(1-\alpha) R$ from Bank $A$ to Bank $B$ per unit of asset when $\widetilde{R}=R$, and a transfer $T$ from Bank $B$ to Bank $A$. This transfer corresponds to an average price $P$ per unit of asset sold and a loan $L$ per unit of asset retained, i.e., $T=\alpha P+(1-\alpha) L$. Note that for a given $T$, the split between $P$ and $L$ is generally indeterminate: A transfer $T$ can be obtained through a variety of combinations of asset-sale price and amount lent as Bank $B$ can earn rents, either by acquiring assets at fire-sale prices or charging a hair-cut while lending to Bank $A$.

If Bank $A$ accepts the offer, it is implemented and bargaining is over. If it rejects the offer then, with probability $\beta$, bargaining breaks down and each bank receives its exogenous outside option: $X_{i} \geq 0$, for $i=A, B$ (see Section 4 for more details). With probability $(1-\beta)$, however, bargaining continues and Bank $A$ gets to make Bank $B$ an offer. If Bank $B$ accepts the offer, it is implemented. Otherwise, bargaining breaks down and each bank receives its outside option.

Two observations are in order. First, the model nests the case of perfect competition, i.e., $\beta=0$. Considering $\beta>0$ allows us to study the effect of Bank $B$ 's outside option. Second, unlike the typical alternating-offers bargaining game of Rubinstein (1982), the surplus to be shared is affected by how it is shared due to specificity of Bank $A$ 's assets.

Finally, we assume that $X_{A}$ and $X_{B}$ are small enough, i.e., there will always be gains from trade between the banks. Since Bank $B$ 's ability to make transfers to Bank $A$ is limited, we assume that trade will be beneficial even if Bank $A$ had to sell all of its assets to Bank $B$, i.e.,

$$
\int_{0}^{1} p_{B}(\theta) R d F(\theta)>X_{A}+X_{B}+\rho .
$$

\footnotetext{
${ }^{12}$ Implicitly, we are assuming that acquiring a bank but leaving its operations unchanged is impossible, i.e., the ownership change has real effects. For brevity, we use this reduced form rather than providing a foundation for the effect of ownership.

${ }^{13}$ Competition in interbank markets has not been studied fully yet, but Cocco et al. (2005) suggest some banks are more important lenders than others. Some players in the interbank markets may be big and pivotal even in normal times. Even if there were no market power in normal times, liquidity crises are often times when the distribution of liquidity is asymmetric and our model is perhaps a best caricature of such extreme events.
} 


\section{The interbank market for liquidity}

We begin by analyzing the perfect competition benchmark and then turn to the case in which Bank $B$ has market power.

\subsection{Perfect competition}

Perfect competition corresponds to $\beta=0$, i.e., Bank $A$ always gets to make the final take-it-or-leave-it offer. Bank $A$ 's optimal offer maximizes its payoff subject to Bank $B$ 's payoff being as high as its outside option. It is easily seen that the optimal offer will satisfy three further properties. First, it must satisfy the incentive compatibility constraint (3), i.e., $r \leq\left(R-R_{b}\right)$. Otherwise Bank $A$ would not monitor its remaining loans and selling them to Bank $B$ would be more efficient. Second, Bank $B$ 's transfer to Bank $A$ must be sufficient to refinance Bank $A$ 's remaining assets. Otherwise these assets would be worthless and selling them to Bank $B$ would again be more efficient. Last, Bank $A$ will sell its most redeployable assets (if any), i.e., all loans with $\theta$ above a threshold $\hat{\theta}$. Therefore Bank $A$ 's problem can be written as:

$$
\begin{array}{ll}
\max _{\hat{\theta}, r, T} & \int_{0}^{\hat{\theta}}\left[p_{H}(R-r)-\rho\right] d F(\theta)+T \\
\text { s.t. } & r \leq\left(R-R_{b}\right) \\
& T \geq F(\hat{\theta}) \rho \\
& \int_{0}^{\hat{\theta}} p_{H} r d F(\theta)+\int_{\hat{\theta}}^{1}\left[p_{B}(\theta) R-\rho\right] d F(\theta)-T \geq X_{B} .
\end{array}
$$

Under the optimal offer $\left(\theta_{A}^{*}, r_{A}^{*}, T_{A}^{*}\right)$, Bank $A$ sells a fraction $\alpha_{A}^{*}=1-F\left(\theta_{A}^{*}\right)$ of its assets.

Proposition 1 Under perfect competition $(\beta=0)$, the outcome is as follows.

- If $p_{H}\left(R-R_{b}\right)-\rho \geq X_{B}$, the outcome is efficient: Bank A's funding needs are met entirely by borrowing from Bank $B$ and no assets are sold (i.e. $\alpha_{A}^{*}=0$ ). Bank $A$ 's expected payoff is

$$
\pi_{A}=p_{H} R-\left(X_{B}+\rho\right) .
$$

- Otherwise, the outcome is inefficient: Bank A sells a fraction $\alpha_{A}^{*}=1-F\left(\theta_{A}^{*}\right)$ of its assets to Bank $B$ with $\theta_{A}^{*}$ defined by

$$
\int_{\theta_{A}^{*}}^{1}\left[p_{B}(\theta) R-p_{H}\left(R-R_{b}\right)\right] d F(\theta)=\left(X_{B}+\rho\right)-p_{H}\left(R-R_{b}\right),
$$

while the remaining assets are refinanced with the sale's proceeds and a loan from Bank $B$. In that case, Bank A's payoff is

$$
\pi_{A}=p_{H} R-\left(X_{B}+\rho\right)-\int_{\theta_{A}^{*}}^{1}\left[p_{H}-p_{B}(\theta)\right] R d F(\theta) .
$$


The intuition is as follows. In equilibrium, Bank $B$ must contribute $\rho$ to finance all of Bank $A$ 's assets in place, and enjoy an expected payoff $X_{B}$. Therefore, Bank $A$ must pledge $\left(X_{B}+\rho\right)$ to Bank $B$, which it can do by borrowing from Bank $B$ or selling it assets. Because assets are best managed by Bank $A$, borrowing is Bank $A$ 's preferred source of funds. Therefore if Bank $A$ 's pledgeable income $p_{H}\left(R-R_{b}\right)$ exceeds $\left(X_{B}+\rho\right)$, Bank $A$ will meet its entire funding needs by borrowing. In that case, it captures the full value of its assets, net of Bank $B$ 's outside option (expression (8)). Otherwise, it must sell some assets to Bank $B$ to finance the shortfall, i.e., expression (9)'s RHS. Indeed owning an asset is more valuable to Bank $B$ than holding a debt claim against it (Assumption 1). Because asset sales are inefficient, Bank $A$ will sell as few assets as needed for the shortfall to be covered by the increased funding capacity these sales allow, i.e., expression (9)'s LHS. In that case, Bank A's payoff is curtailed by the inefficiency associated with asset sales, i.e., expression (10)'s last term. The larger the shortfall, the more assets need to be sold and the more inefficient is the outcome.

\subsection{Imperfect competition}

Consider now imperfect competition $(\beta>0)$. We solve the model by backward induction. If Bank $A$ gets to make the final offer, the outcome is as in Proposition 1. In the previous stage, Bank $B$ makes the first offer. When deciding whether to accept the offer, Bank $A$ must consider the possibility that bargaining will break down, which happens with probability $\beta$. Hence Bank $A$ will accept an offer only if its expected payoff is at least

$$
E\left(\pi_{A}\right)=\beta X_{A}+(1-\beta) \pi_{A} .
$$

As before, the optimal offer satisfies three further properties: Bank $A$ will sell its most redeployable assets, i.e., with $\theta$ above some threshold $\hat{\theta}$, and set $r \leq\left(R-R_{b}\right)$ and $T \geq F(\hat{\theta}) \rho$. Hence, Bank $B$ 's problem can be stated as:

$$
\begin{array}{ll}
\max _{\hat{\theta}, r, T} & \int_{0}^{\hat{\theta}} p_{H} r d F(\theta)+\int_{\hat{\theta}}^{1}\left[p_{B}(\theta) R-\rho\right] d F(\theta)-T \\
\text { s.t. } & r \leq\left(R-R_{b}\right) \\
& T \geq F(\hat{\theta}) \rho \\
& \int_{0}^{\hat{\theta}}\left[p_{H}(R-r)-\rho\right] d F(\theta)+T \geq E\left(\pi_{A}\right)
\end{array}
$$

Under the optimal offer $\left(\theta^{*}, r^{*}, T^{*}\right)$, Bank $A$ sells a fraction $\alpha^{*}=1-F\left(\theta^{*}\right)$ of its assets.

Proposition 2 The negotiation's outcome is as follows.

- If $E\left(\pi_{A}\right) \geq p_{H} R_{b}$, the outcome is efficient: Bank A's funding needs are met entirely by borrowing from Bank $B$ and no assets are sold (i.e. $\alpha^{*}=0$ ).

- Otherwise, the outcome is inefficient: Bank A sells a fraction $\alpha^{*}=\left(1-E\left(\pi_{A}\right) / p_{H} R_{b}\right)$ of its assets to Bank $B$ (i.e. all loans with $\theta>\theta^{*}=F^{-1}\left(E\left(\pi_{A}\right) / p_{H} R_{b}\right)$ ) while the remaining assets are refinanced with the sale's proceeds and a loan from Bank $B$. 
Bank $B$ aims to acquire as many of Bank $A$ 's assets as possible subject to Bank $A$ getting its reservation payoff. Indeed, under Assumption 1, a sale is the most effective way of transferring value from Bank $A$ to Bank $B$. For instance, for $E\left(\pi_{A}\right)=0$, Bank $B$ acquires all of Bank $A$ 's assets for free, i.e., sets $\alpha^{*}=\theta^{*}=1$ and $T^{*}=0$. As $E\left(\pi_{A}\right)$ increases, Bank $B$ must ensure that Bank $A$ accepts its offer. The most efficient way of increasing Bank $A$ 's payoff is for Bank $B$ to leave it some assets and refinance them, i.e., $T=F(\hat{\theta}) \rho$. Because Bank $A$ is best at managing its assets, this is preferred to Bank $B$ making a cash transfer to Bank $A$ above the funding needs. In that case, Bank $A$ should obviously keep its least redeployable assets. For the same reason, maximizing $r$ is always weakly optimal, i.e., $r^{*}=\left(R-R_{b}\right)$. Indeed, leaving Bank $A$ with a stake exceeding $R_{b}$ on an asset is akin to a cash transfer. In turn $\alpha^{*}$ is determined by Bank $A$ 's participation constraint. When $E\left(\pi_{A}\right)=0$, Bank $B$ acquires all of Bank $A^{\prime}$ 's assets $\left(\alpha^{*}=1\right)$. As $E\left(\pi_{A}\right)$ increases, Bank $B$ must leave Bank $A$ some assets financed with borrowing with $r=R-R_{b}$. Hence, for each asset, Bank $A^{\prime}$ 's expected payoff is $p_{H} R_{b}$. Hence $\alpha^{*}$ is determined by $\left(1-\alpha^{*}\right) p_{H} R_{b}=E\left(\pi_{A}\right)$.

\subsection{Properties}

We now highlight some properties of the outcome. Bank $A$ selling all of its assets with $\theta>\theta^{*}$ involves a deadweight loss

$$
K^{*} \equiv \int_{\theta^{*}}^{1}\left(p_{H}-p_{B}(\theta)\right) R d F(\theta) .
$$

We begin with the effect of Bank $B$ 's market power on the equilibrium liquidity transfer.

Corollary 1 Efficiency (weakly) decreases with Bank B's market power. More precisely,

- A threshold $\beta^{*} \in[0,1]$ exists such that the outcome is efficient if and only if $\beta<\beta^{*}$.

- For $\beta>\beta^{*}$, asset sales and the associated inefficiency increase strictly with $\beta$.

- In some cases, the outcome is efficient only if competition is intense enough: $\beta^{*} \in$ $(0,1)$.

The intuition for the existence of a threshold $\beta^{*}$ is as follows. Bank $B$ does not acquire assets when $E\left(\pi_{A}\right) \geq p_{H} R_{b}$. Since $E\left(\pi_{A}\right)$ decreases with $\beta$, a threshold $\beta^{*}$ exists such that asset sales occur only if $\beta>\beta^{*}$. If $p_{H} R_{b}>X_{A}$, there will be asset sales if Bank $B$ is certain to make an offer $(\beta=1)$ and therefore $\beta^{*}<1$. If $p_{H}\left(R-R_{b}\right)-\rho>X_{B}$, no assets are sold if Bank $B$ cannot make an offer $(\beta=0)$ and therefore $\beta^{*}>0$.

The intuition for the fraction of Bank $A$ 's assets sold increasing with $\beta$ (for $\beta>\beta^{*}$ ) is as follows. When $\beta$ increases, Banks $A$ 's reservation payoff $E\left(\pi_{A}\right)$ decreases. Therefore, Bank $B$ must transfer less value to Bank $A$. Once Bank $A$ has exhausted its borrowing capacity, it must start selling assets to Bank $B$ even though this is inefficient, as this is the most effective means of transferring value to Bank $B$ (Assumption 1). 
Our analysis (Corollary 1) shows that the market power of liquid banks can lead to an inefficient allocation of liquidity even in situations where the allocation would be efficient if those same banks were perfectly competitive. This scenario corresponds to $\beta>\beta^{*}>0$. There are also situations in which frictions in the interbank market (here, moral hazard in monitoring) would lead to an inefficient allocation of liquidity even if liquid banks were perfectly competitive. This corresponds to $\beta^{*}=0$. In those situations, liquid banks' market power increases the inefficiency of the allocation of aggregate liquidity. It is important to stress that market power alone would not lead to an inefficient outcome. Indeed, absent moral hazard in monitoring, Bank $B$ would be able to increase its interest rate without affecting the value of Bank $A$ 's asset. It would find it optimal to do so since Bank $A$ 's assets are bank-specific. The reason why Bank $B$ 's market power would not lead to an inefficient allocation is that we allow its offer to Bank $A$ to specify both price and quantity.

Corollary 2 Efficiency (weakly) decreases with the liquidity need $\rho$ and with Bank $B$ 's outside option $X_{B}$, and increases with Bank $A$ 's outside option $X_{A}$. Formally, an increase in $\rho$, an increase in $X_{B}$, and a decrease in $X_{A}$ all have the following effect:

- $\beta^{*}$ decreases weakly for $\beta^{*}=1$ and strictly for $\beta^{*} \in(0,1)$.

- For $\beta>\beta^{*}$, asset sales and the associated inefficiency increase.

The intuition is that by reducing Bank $A$ 's reservation payoff $E\left(\pi_{A}\right)$, an increase in $X_{B}$ or a decrease in $X_{A}$ tilts the bargaining outcome towards Bank $B$ 's interest which is to acquire more of Bank $A$ 's loans. If $\beta>\beta^{*}$, Bank $A$ has exhausted its borrowing capacity and an increase in $\rho$ requires it to sell more loans to Bank $B$. The properties of $\alpha^{*}$ imply those of $\beta^{*}$.

\section{Loan characteristics}

In this section, we focus on how the specificity of Bank $A$ 's assets affects the outcome. We model explicitly the fact that Bank $A$ has access to competitive outside markets for borrowing and asset sales. We assume that Bank $B$ has an advantage over outsiders both for using Bank $A$ 's assets and for lending against them, which we model as follows.

Asset sales: If an outsider owns a loan of Bank $A$ with characteristic $\theta$, then $p=p_{o}(\theta)$. We assume that Bank $B$ has an advantage over outsiders for managing Bank $A$ 's assets. That is, banks are special relative to outsiders, e.g., better monitors of small, relationshipspecific loans (e.g., Fama (1985), James (1987), James and Houston (1996)). Moreover, we assume that those projects for which Bank $A$ 's advantage over Bank $B$ is the greatest are also those for which Bank $B$ 's advantage over outsiders is the greatest, i.e., loans' Bank $A$-specificity and their bank-specificity relative to outsiders are correlated:

$$
p_{o}(\theta)<p_{B}(\theta) \quad \text { and } \quad \frac{d p_{o}(\theta)}{d \theta}>\frac{d p_{B}(\theta)}{d \theta}
$$


Nevertheless, we assume it is efficient to refinance Bank $A$ 's loans even if owned by an outsider:

$$
p_{o}(\theta)>\rho / R
$$

Borrowing: We assume that Bank $B$ is more effective than outsiders at making loans to Bank $A .{ }^{14}$ Specifically, we assume that when borrowing from outsiders, Bank $A$ 's benefit from not monitoring is $b_{o} \geq b$, so that it must retain a larger exposure to its loans to have an incentive to monitor, i.e., $R_{b}^{o} \equiv b_{o} / \Delta p \geq R_{b}$.

To simplify, we assume again that Bank $A$ can raise more funds by selling outsiders a loan than by pledging some of its return to them

$$
\forall \theta \in[0,1], p_{o}(\theta) R>p_{H}\left(R-R_{b}^{o}\right)
$$

The outcome is obtained from Proposition 1 by replacing Bank $B$ 's characteristics with the outsiders', i.e., by setting $X_{B}=0, b=b_{o}$ and $p_{B}=p_{o}$. The intuition is therefore similar. If Bank $A$ 's borrowing capacity $p_{H}\left(R-R_{b}^{o}\right)$ exceeds its funding need $\rho$, Bank $A$ should only borrow from outsiders as this is more efficient. Otherwise, it must sell some assets to outsiders.

Lemma 1 If bargaining between banks $A$ and $B$ breaks down, the outcome is as follows.

- If $p_{H}\left(R-R_{b}^{o}\right)-\rho \geq 0$, the outcome is efficient: Bank A's funding needs are met entirely by borrowing from outsiders and no asset sale (i.e. $\alpha_{o}^{*}=0$ ). Bank $A$ 's expected payoff is

$$
X_{A}=p_{H} R-\rho
$$

- Otherwise, the outcome is inefficient: Bank A sells a fraction $\alpha_{o}^{*}=1-F\left(\theta_{o}^{*}\right)$ of its assets to outsiders with $\theta_{o}^{*}$ defined by

$$
\int_{\theta_{o}^{*}}^{1}\left[p_{o}(\theta) R-p_{H}\left(R-R_{b}^{o}\right)\right] d F(\theta)=\rho-p_{H}\left(R-R_{b}^{o}\right),
$$

\footnotetext{
${ }^{14}$ Peer monitoring among banks is considered important because interbank loans are large and unsecured (see Rochet and Tirole (1996), and Freixas and Holthausen (2005) for theory and Furfine (2001) and Cocco et al. (2005) for evidence). Also, interbank lending relationships are seen to mitigate agency problems. Furfine (2001) and Cocco et al. (2005) suggest that large banks, in terms of size as well as participation in interbank lending, enjoy market power in lending: they borrow and lend at more favorable terms, and often small banks, with limited access to foreign interbank markets, concentrate all their borrowing in the domestic interbank markets relying on a few lending relationships with large banks. Cocco et al. also highlight the essentially bilateral nature of interbank lending: most of the lending volume is accounted for by "direct" loans where loan amount and interest rate are agreed on a one-to-one basis between borrower and lender, other banks do not necessarily have access to the same terms and may not even observe the transaction, and posted quotes are merely indicative. The bilateral nature of the market is also evidenced in that the identity of lending banks affects the interest rate. Cocco et al. find that banks with higher return on assets lend at higher interest rates, more profitable banks lend less.
} 
while the remaining assets are refinanced with the sale's proceeds and a loan from outsiders. In that case, Bank A's payoff is

$$
X_{A}=p_{H} R-\rho-\int_{\theta_{o}^{*}}^{1}\left[p_{H}-p_{o}(\theta)\right] R d F(\theta) .
$$

We can now analyze bargaining between banks $A$ and $B$. For now, we assume that Bank $B$ 's outside option $X_{B}$ is independent of Bank $A$ 's distribution of loan characteristics $F$. Recall that Bank $A$ sells all its loans with $\theta$ above $\theta^{*}$. This threshold does depend on the distribution of loan characteristics. Hence the fraction $\alpha^{*}$ of its assets Bank $A$ sells to Bank $B$ depends on $F$ directly but also through its effect on $\theta^{*}$.

Proposition 3 Efficiency increases with the outsiders' ability to monitor loans to Bank $A$, with their ability to run assets, and with the redeployability of Bank A's assets. More precisely, for $\beta>\beta^{*}$, a decrease in $b_{o}$, an increase in the function $p_{o}(\cdot)$ or a shift of the distribution $F$ towards higher values in the sense of FOSD results in fewer asset sales and a lower inefficiency.

The effect of a decrease in $b_{o}$ or an increase in $p_{o}(\cdot)$ is simple. Indeed, such changes increase $X_{A}$ but keep all other variables constant. Therefore, this result is a simple implication of Corollary 2. The effect of a shift of $F$ is more complex as it affects not only Bank $A$ 's outside option in its bargaining with Bank $B$ but also other variables relevant to that bargaining.

Our analysis implies that the market failure in the transfer of liquidity is more severe when banks that need liquidity have a large share of their portfolio in small, relationshipspecific loans, as this decreases the outside option of needy banks, giving surplus banks a better opportunity to exert market power and exploit needy banks' difficulties.

\section{Central bank as lender-of-last-resort}

We have shown how surplus banks' market power can worsen or even create inefficiencies in the interbank market. An important implication is that an aggregate liquidity surplus is no guarantee that liquidity will find its way to banks needing it most in an efficient way. In this context, we study how a central bank acting as a lender-of-last-resort (LOLR) can mitigate inefficiencies by curbing surplus banks' ability to exploit their market power. We also determine the conditions under which such an improvement occurs.

Note that our analysis side-steps the issue of the central bank's optimal policy. Here, we focus only on ex-post effects of central bank intervention. However, central bank actions can affect bank behavior ex ante, e.g., lead to moral hazard and mismanagement of liquidity and credit risk (Repullo (2005) and Acharya, Shin and Yorulmazer (2007)). We also do not analyze optimality of the intervention from ex-post or ex-ante standpoint. Indeed our model as it stands is ill-suited for such an analysis as it does not specify 
explicitly the limits to central bank intervention. Hence, taking the model literally, the central bank could "force" the efficient allocation of liquidity by setting directly the liquidity transfers between banks. For instance, it could set caps on interest rates and floors on asset prices. In practice, several problems might make such direct intervention less effective and a meaningful analysis of optimal regulation should account for these.

We amend the model as follows. If bargaining with Bank $B$ breaks down, Bank $A$ can first seek liquidity from from a central bank and then from competitive outside markets. ${ }^{15}$ When borrowing from the central bank, Bank $A$ 's benefit from not monitoring is $b_{C}$, and we define $R_{b}^{C} \equiv b_{C} / \Delta p$. We assume that Bank $B$ is better than the central bank at making loans to Bank $A$, i.e., $b_{C} \geq b$. To simplify, assume that the central bank has full bargaining power against Bank $A$. We assume that ex post, the central bank maximizes social surplus subject to its expected losses not exceeding some level $\Lambda \geq 0$.

Finally, denote $\beta_{o}^{*}$ the value of $\beta^{*}$ absent any intervention by the central bank. If $\beta<\beta_{o}^{*}$, the efficient outcome is reached, i.e., Bank $A$ does not sell any of its loans and refinances them all. In that case, there is no role for the central bank. Instead, we now assume that $\beta>\beta_{o}^{*}$ and study the effect of central bank acting as a LOLR.

\subsection{Central bank intervention}

We discuss the form of the central bank's ex post optimal intervention. Since the central bank is, up to a limit, willing to extend some potentially loss-making loans, it would be willing to make a transfer to Bank $A$ of up to $\Lambda$, or a larger transfer against some claim on Bank A's assets.

Proposition 4 The central bank's optimal intervention depends on whether it is better than outsiders at monitoring Bank A.

- If it is not (i.e., $b_{C} \geq b_{o}$ ), its optimal intervention amounts to a pure transfer to Bank $A$

$$
T_{C}=\min \left\{\Lambda, \rho-p_{H}\left(R-R_{b}^{o}\right)\right\} .
$$

Bank $A$ should borrow $p_{H}\left(R-R_{b}^{o}\right)$ from outsiders and sell them the remaining loans if any.

- If it is (i.e., $b_{C}<b_{o}$ ), its optimal intervention amounts to lending to Bank $A$ and possibly making it a pure transfer

$$
L_{C}=p_{H}\left(R-R_{b}^{C}\right) \quad \text { and } \quad T_{C}=\min \left\{\Lambda, \rho-p_{H}\left(R-R_{b}^{C}\right)\right\} .
$$

Bank A should not borrow from outsiders, only sell them the remaining loans if any.

- In both cases, as the central bank's maximum expected loss $\Lambda$ increases, asset sales decrease.

\footnotetext{
${ }^{15}$ For simplicity, we assume that the central bank cannot buy Bank $A$ 's assets. The central bank owning assets could correspond to nationalization of some or all of Bank $A$ 's assets.
} 
Consider first the case of a central bank that is no better than outsiders at monitoring loans to Bank $A$. In that case, loans should be made only by outsiders, i.e., the central bank should not use Bank $A$ 's limited borrowing capacity. Moreover, outsiders being competitive, they make zero profits and so there is no action by the central bank that can induce them to extend more loans. Hence the central bank's actions do not affect Bank $A$ 's borrowing capacity. The only action the central bank can take is to make (what amounts to) a pure transfer to Bank $A$. Such a transfer can be implemented in different ways: a pure transfer, or possibly a guarantee of Bank $A$ 's debt towards outsiders. Importantly, however, the central bank should not receive claims on Bank A's cash flows as outsiders value these more.

Consider now the case of a central bank that is better than outsiders at monitoring loans to Bank $A$. This advantage may, for instance, stem from the central bank's supervisory role. In that case, it should substitute itself to outsiders, i.e., the outsiders should not use Bank A's limited borrowing capacity. The central bank increases Bank A's borrowing capacity, which eventually reduces the need for inefficient asset sales.

There is no room for collateral or secured lending as such in our model. However, the central bank's potential loss maps effectively into a liquidity transfer, which in turn can be interpreted as lowering the quality of collateral against which the central bank extends liquidity support, e.g., by lending to needy banks against mortgages at a higher rate than the market does if these loans are likely to be terminated in absence of liquidity support.

For a given $b_{C}$, define $\Lambda^{*}\left(K, b_{C}\right)$ as the level of potential losses the central bank must incur to achieve efficiency loss no greater than $K$.

Corollary 3 If the central bank is better than outsiders at monitoring Bank A (i.e., $\left.b_{C}<b_{o}\right)$, the expected loss it must incur to achieve a given level of efficiency decreases with its ability to monitor Bank A, i.e.,

$$
\frac{\partial \Lambda^{*}\left(K, b_{C}\right)}{\partial b_{C}}>0
$$

As $b_{C}$ decreases, Bank $A$ can pledge a larger fraction of its return to the central bank so that loss-making loans are less costly to the central bank. Or, in other words, through its supervisory role, the central bank can limit its losses.

\subsection{Impact on interbank market outcomes}

We can now study how the possibility of central bank intervention ex post affects the bargaining between banks $A$ and $B$ ex ante. As a benchmark, consider a central bank that is neither better than outsiders at monitoring Bank $A$ nor willing to accept any potential losses.

Proposition 5 A central bank that is no better than outsiders at monitoring Bank $A$ (i.e., $b_{C} \geq b_{o}$ ) and/or is not ready to accept any potential losses (i.e., $\Lambda=0$ ) cannot ameliorate the inefficiency arising from Bank B's market power. 
The intuition is simple. Indeed, if the central bank is able and willing to take a given action, so is any of the outsiders. In effect, the central bank is like an outsider, possibly one that is less effective at extending loans. Hence, Bank $A$ 's outside option is the same as absent the central bank and the outcome of its negotiation with Bank $B$ is unchanged.

Turning the result on its head, we can characterize situations in which central bank intervention can have an impact.

Proposition 6 The central bank can improve outcomes if it is better than outsiders at monitoring Bank $A$ (i.e., $b_{C} \geq b_{o}$ ) and/or is ready to accept potential losses (i.e., $\Lambda>0$ ). Moreover, loans sales and the associated inefficiency decrease with the central bank's ability to monitor Bank A (if it exceeds that of outsiders) and with its willingness to make losses, i.e.,

$$
\left(\frac{\partial \alpha^{*}}{\partial b_{C}}\right)>0 \text { and }\left(\frac{\partial \alpha^{*}}{\partial \Lambda}\right)<0 \text {. }
$$

The central bank can improve outcomes without actually extending loans in equilibrium, i.e., it can play a "virtual and virtuous" role: It is sufficient that it provides potential competition to Bank $B$. By acting as a LOLR, the central bank can improve Bank $A$ 's outside option in its negotiation with Bank $B$, provided that the central bank is either better than outsiders at monitoring Bank $A$ or willing to extend loss-making loans. ${ }^{16}$

We find that unless the central bank is a more effective lender than outsiders, its loans would have to be potentially loss-making. This in turn raises several issues: (i) if the central bank stands as a LOLR, it will have incentives to improve its ability to make loans, e.g., to assess and monitor borrowing banks; and (ii) it may be optimal to assign other tasks (e.g., supervision) to the central bank if they increase its expertise in monitoring loans. This argument differs from that saying that since the central bank is a LOLR, it ought to supervise/monitor banks to avoid that they be in a position to need the LOLR.

\section{Ex-ante liquidity insurance}

So far, we have considered liquidity transfers once a liquidity shock has occurred, ignoring the possibility for banks to insure against such shocks as considered by Bhattacharya and Gale (1987), Allen and Gale (2000), and Leitner (2005), among others. We now consider the possibility for Bank $A$ to insure, completely or partially, against liquidity shocks. We modify the model as follows.

\footnotetext{
${ }^{16}$ Berger et al. (2000) test the hypothesis that supervisors have more accurate information than the market on the soundness of financial institutions using data from the US. They show that shortly after supervisors have inspected a bank, supervisory assessment of the bank is more accurate than the market. However, for periods where the supervisory information is not up-to-date, the market has more accurate information than supervisors.

Note that our results would be stronger if we allowed the central bank to be more efficient than other banks in monitoring. However, what we derive is a stronger result as we show that even a central bank that is not necessarily as efficient as other banks in monitoring can decrease the inefficiency in liquidation.
} 
At $t=0$, Bank $A$ can approach Bank $B$ to organize liquidity insurance. We do not consider the possibility for Bank A to get liquidity insurance from outsiders. This appears to be consistent with banks being special in provision of lines of credit, not just to other borrowers in the economy but also to each other. Also, for simplicity, we assume that Bank $A$ makes Bank $B$ a take-it-or-leave it offer.

At $t=1$, Bank $A$ 's loans need refinancing of $\rho$ units of cash with probability $x$, and no refinancing otherwise. Whether Bank $A$ incurs a liquidity shock or not is verifiable. If Bank $A$ incurs a liquidity shock, Bank $B$ 's opportunity cost of capital is $\mu>1$ with probability $y$ and 1 otherwise. We assume that $p_{H} R-\mu \rho<0$, i.e., if Bank $B$ 's opportunity cost is high, efficiency requires that Bank $B$ does not transfer funds to Bank $A$. We assume that Bank B's opportunity cost of capital is not verifiable. At that point, banks $A$ and $B$ can renegotiate their contract.

Finally, we make simplifying assumptions. First, we assume that all of Bank $A$ 's loans have the same characteristic $\theta \cdot{ }^{17}$ Second, we assume that Bank $B$ cannot pledge any of its assets to Bank $A$. This ensures that if Bank $B$ makes a transfer to Bank $A$ but turns out to have a high cost of capital, Bank $A$ will not transfer back the appropriate amount of liquidity to Bank $B$. Third, we assume that Bank $B$ has full bargaining power at the contract renegotiation stage (i.e., $\beta=1$ ). Fourth, we assume that outside markets are so weak that only Bank $B$ can refinance Bank $A$ 's loans, i.e., any loan not refinanced by Bank $B$ must be terminated.

There are three states of the world. In principle, Bank $A$ 's offer specifies for each state of the world three components per state of the world $\omega \in\{(\rho, 1),(\rho, \mu),(0,1)\}$ a transfer $T(\omega)$ from Bank $B$ to Bank $A$, a set of loans of measure $\alpha(\omega)$ transferred to Bank $B$, and a claim $r(\omega)$ by Bank $B$ on Bank $A$ 's remaining assets. However, the fact that Bank $B$ 's cost of capital is not observable constrains the set of feasible contracts at $t=0$. In can be shown that the contract's terms cannot differ across states $(\rho, 1)$ and $(\rho, \mu)$.

Proposition 7 An optimal contract at $t=0$ is as follows. ${ }^{18}$ Define

$$
T^{*} \equiv \frac{(1-x) p_{H}\left(R-R_{b}\right) \rho}{x\left[(1-y)\left(p_{B} R-p_{H}\left(R-R_{b}\right)\right)+y \frac{R_{b}}{R} \mu \rho\right]} .
$$

- If $T^{*} \geq \rho$, Bank A gets full liquidity insurance from Bank $B$ so that no loans is sold to Bank $B$ in the event of a liquidity shock, i.e., $T(\rho)=\rho$.

- If $T^{*}<\rho$, Bank A gets only partial liquidity insurance from Bank B, i.e.,

$$
T(\rho)=T^{*} \text {. }
$$

If Bank A incurs a liquidity shock, Bank B acquires a fraction $\alpha^{*}$ of Bank A's loans with

$$
\alpha^{*}=1-\frac{T^{*}}{\rho} .
$$

\footnotetext{
${ }^{17}$ With heterogeneous values of $\theta$, the optimal contract would generally involve some asset sale to Bank $B$ even when Bank $A$ does not incur a liquidity shock. Indeed, the sale of more liquid loans absent a shock could avoid the sale of less liquid loans in the event of a shock.

${ }^{18}$ This contract is not uniquely optimal. Indeed, a contract with some asset sales when there is no shock and less sales when there is a shock can also be optimal.
} 
Corollary 4 The fraction of loans Bank A sells following a liquidity shock, and the associated inefficiency increase with the probability $x$ of a liquidity shock for Bank $A$, the probability $y$ that Bank B's cost of capital is high, and with the value of Bank B's high cost of capital $\mu$.

In other words, as a shock becomes more likely, there is less scope for liquidity insurance. As $y$ and/or $\mu$ increase, Bank $B$ is less keen to commit to a transfer to Bank $A$. The implication of this is that when aggregate liquidity shortage is more likely, there is less insurance written ex ante. In turn, even if the aggregate liquidity shortage does not arise, the surplus banks are left with greater ability to exploit their market power against cash-stricken banks. Finally, another implication of the proposition is that as long as only partial liquidity insurance is obtained in equilibrium, the central bank can improve efficiency by acting as a lender of last resort.

\section{Robustness and discussion}

Before proceeding to discuss in greater detail the implications of our model and results for central bank's role as lender of last resort, we discuss some theoretical issues concerning their robustness.

\subsection{Asymmetric information}

Asymmetric information is an important alternate candidate that can result in a failure of inter-bank markets (Bhattacharya and Gale (1987), Flannery (1996), and Freixas and Jorge (2007)). While it is difficult to resolve theoretically which one of asymmetric information and moral hazard is the more important driver of limited liquidity, our model suggests that the role of central banking in the two cases is likely to be quite different. For instance, in a model with asymmetric information, a central bank not prepared to make losses on its loans can help ex post only if it is a better monitor of needy banks relative to surplus banks. In our model in contrast, the central bank can help even if it is worse than surplus banks in monitoring needy banks as long as it is better than outsiders. Further, with asymmetric information, the central bank will in equilibrium lend to needy banks in order to improve ex post outcomes, unless it can credibly convey its information to surplus banks. In our model, the central bank need not lend in equilibrium; that is, it can play a virtual and virtuous role as its mere credibility as a lender of last resort weakens surplus banks' bargaining power.

\subsection{Market power relative to outsiders}

While altering the order of bargaining between surplus and needy banks does not affect results substantially, the nature of market power of the surplus bank with respect to outsiders raises interesting questions. First, how would outcomes be affected if the surplus 
bank has better lending power but the outside markets to sell assets are associated with better asset management skills? Is the confluence of market power of the surplus bank in both lending and asset sale markets necessary for inefficiency asset sales to arise? While we have not analyzed this case formally, we conjecture that the answer to the latter question is in the affirmative.

Second, under the model assumptions, outsiders have incentives to supervise banks and assume some of the roles of the regulator since there are rents to be captured from such monitoring and improved ability to offer liquidity to needy banks. One reason outsiders may not succeed in gaining such a strategic advantage is that banks may be more forthcoming to disclose information to the regulator, anticipating that such information will not be used against them competitively, whereas outsiders, who may be (or could in future become) players in similar markets as banks, may not be credible in not exploiting such information for their own advantage. The historical evidence in Appendix B of the competitive behavior of commercial central banks during crises reinforces this point. The player that reduces the bargaining power of surplus banks must be a non-competitive, non-profit maximizing institution such as the central bank.

\subsection{Market power relative to central bank}

Similarly, the nature of game between the surplus bank and the central bank raises important questions. We showed that the effectiveness of the central bank in curbing the market power of the surplus bank is increasing in the quality of its supervision (given the amount of losses the central bank is prepared to suffer on its loans). We modeled the quality of supervision as central bank's ability to lower the private benefits extracted by the needy bank. However, the central bank knew with certainty that the state was not in fact one with aggregate liquidity shortage.

Suppose instead that the cost of capital $(\mu)$ of the surplus bank is only partially observed by the central bank. Then, the central bank has limited powers to coerce the surplus bank into supplying liquidity. It would now have to bargain with the surplus bank, possibly leaving them with rents. ${ }^{19}$ We leave aside for now a fuller modeling of this game.

\footnotetext{
${ }^{19}$ The financial crisis in the UK and the bailout and subsequent nationalization of Northern Rock in 2007 showed that surplus banks can exert power not only on needy banks but also on authorities (see "The Bank loses a game of chicken," Financial Times, 9/20/2007; "Lessons of the fall," The Economist, 10/8/2007): On 8/13/2007, Northern Rock approached regulatory authorities in the UK (the Bank of England, the HM Treasury and the Financial Services Authority) and informed them about its liquidity problems. By mid-September, the longer-term funding markets were closed for Northern Rock. While the possibility of Bank of England acting as a lender of last resort had been discussed among the authorities, the option of selling Northern Rock to another bank had been tried first. While Lloyds TSB emerged as a serious contender, the deal did not go through since Lloyds' demand for a loan of up to £30 billion from the Bank of England had been rejected by the tripartite authorities on the grounds that it would not be appropriate to help finance a bid by one bank for another. The case of Bear Stearns' acquisition by J.P.Morgan Chase in March 2008 has been much the same, except that the Fed provided a loan of up to $\$ 30$ billion for the acquisition (see footnote 6 for details).
} 


\section{Implications for policy and broader financial mar- kets}

\subsection{The discount window}

The result that central banks do not lend in equilibrium but merely change needy banks' outside option, forcing surplus banks to adjust their liquidity supply, has implications for discount windows in central banks' lender-of-last-resort facilities and their usage by banks.

Usually, the discount window (e.g. the US Fed's) offers banks a lending facility at a premium to the federal funds rate, i.e., the rate at which banks (depository institutions) lend their balances at the Fed to other banks, usually overnight. The discount window's purpose has been a puzzle to many as it is seldom used. Some have argued that a bank borrowing from the discount window would be seen as having funding problems in interbank and other markets, and that this "stigma" explains banks' reluctance to use the discount window. Our analysis implies that this reluctance need not mean that the discount window serves no purpose. The federal funds rate plus the premium sets an upper bound on the cost of borrowing when aggregate liquidity is in surplus. In particular, this limits the rents surplus banks can squeeze out of needy banks.

A second implication concerns the discount window premium. How high should the premium be? Could it be so high that it has little effect on borrowing outcomes? ${ }^{20}$ Lack of borrowing at the discount window by itself should not cause as much alarm as lack of any effect of changing the premium at the discount window on interbank borrowing rates, an issue that has not received significant attention. In the context of our model, the discount window would have no effect on borrowing outcomes if the lending rate at the window is not below that at which outside (non-bank) markets would lend against the same assets. Indeed, the central bank may find it desirable to commit to bearing some potential losses in which case the effective lending rate at the window should be below the outside market rate. Historically, there has been some evidence of such use of discount window at discount to federal funds rate (rather than at premium) having been effective during the 1970 Penn Central commercial paper crisis. $^{21}$

\footnotetext{
${ }^{20}$ For example, in August 2007, the Fed cut the discount rate to just a half percentage point above the federal funds rate, from the usual spread of a full point, hoping to encourage banks to seek funds from the window to help customers finance holdings of illiquid securities. Fed officials told banks at the time that any such borrowing would be seen as a sign of strength, not weakness. "This change did not lead to a big increase in borrowing ... (because) even at a (half point) spread, the (discount) rate was higher than the rate on alternative sources of funds for most depository institutions," William Dudley (Executive Vice President), who managed open market operations at the New York Fed at that time, told an audience at the Philadelphia Fed in October 2007.

${ }^{21}$ Calomiris (1994) describes the crisis, and the Fed's use of the discount window to combat it. The Fed lent to member banks through the discount window for purposes of making loans to commercial paper issuers. Importantly, funds were lent at a discount to the federal funds rate, rather than the normal premium, which succeeded in channeling liquidity to needy institutions reliant on commercial paper market during normal times. Firms likely to have had outstanding debt in the form of commercial paper suffered larger negative abnormal returns during the onset of the crisis, and larger positive ones after the Fed intervened to lower the cost of commercial paper rollover.
} 
It is an important consideration as to whether central bank needs to lend to individual institutions or can succeed in channeling liquidity to needy banks simply through open market operations (OMO) (Goodfriend and King, 1988). Our model implies that when there are market power issues, the central bank operations through OMOs may not succeed in their objective or the central bank may need to pump very large amounts of liquidity to break the market power of some banks. Consistent with this view, during the hearings about the Northern Rock episode in Fall of 2007, Governor of Bank of England Mervyn King and the Chancellor of the Exchequer Alistair Darling pointed out the difficulties with OMOs in channeling liquidity to needy banks as the primary reason for lending directly to individual institutions. In particular, they pointed out that to channel the $£ 14$ billion Northern Rock borrowed from the Bank of England to that institution would have required many more billions of pounds to be injected through the OMOs.

\subsection{New forms of central bank funding}

Our analysis also implies that unless outside markets are themselves strapped of liquidity, needy banks should have no trouble raising liquidity against collateral requiring little monitoring skills or expertise. Illiquidity issues arise for those loans over which other banks have an advantage in terms of monitoring and usage, conferring upon them market power during crises. Indeed, collateral that is highly bank-specific may be inefficiently liquidated. Hence, a discount window or other lender-of-last-resort facility that lends only against high-quality collateral may not improve much the allocation of liquidity among banks.

This perspective is useful for understanding the new facilities set up by the Fed in 2007-09 aimed at channeling liquidity to the most needy corners of the financial system. These new facilities have extended maturities to include up to 90-day loans, maturities at which money markets have dried up in the aftermath of sub-prime losses; extended eligible collateral to include investment-grade debt securities (including high-rated but illiquid mortgage-backed securities); and, extended these privileges to not just banks but also to securities dealers since these are also affected by funding problems due to drying up of liquidity extension from banks. ${ }^{22}$ These changes are more likely to be effective than traditional facilities in restoring liquidity of interbank markets, even if they are not

\footnotetext{
${ }^{22}$ In particular, in addition to the traditional tools the Fed uses to implement monetary policy (e.g., Open Market Operations, Discount Window, and Securities Lending program), new programs have been implemented since August 2007: 1) Term Discount Window Program (announced 8/17/2007) - extended the length of discount window loans available to institutions eligible for primary credit from overnight to a maximum of 90 days; 2) Term Auction Facility (TAF) (announced 12/12/2007) - provides funds to primary credit eligible institutions through an auction for a term of 28 days; 3 ) Single-Tranche OMO (Open Market Operations) Program (announced 3/7/2008) - allows primary dealers to secure funds for a term of 28 days. These operations are intended to augment the single day repurchase agreements (repos) that are typically conducted; 4) Term Securities Lending Facility (TSLF) (announced 3/11/2008) - allows primary dealers to pledge a broader range of collateral than is accepted with the Securities Lending program, and also to borrow for a longer term — 28 days versus overnight; and, 5) Primary Dealer Credit Facility (PDCF) (announced 3/16/2008) - is an overnight loan facility that provides funds directly to primary dealers in exchange for a range of eligible collateral; 6) Commercial Paper Funding Facility (CPFF) (announced 11/7/2008) - is designed to provide a liquidity backstop to U.S. issuers of commercial paper; 7) Money Market Investor Funding Facility (MMIFF) (announced 11/21/2008) - is
} 
directly tapped into, since they have created a direct option for raising funding against assets rendered illiquid. ${ }^{23}$

In the early stages of the crisis of 2007-2009, the Federal Reserve used open market operations to ease the strain in money markets. While OMOs had some success in stabilizing the overnight rate, the rates on term loans continued to rise. On December 12, 2007, the Federal Reserve introduced the Term Auction Facility (TAF), which provides term funding to eligible depository institutions through auctions. McAndrews et. al. (2008) analyze whether TAF had success in easing the strain in money markets, measured as downward shifts in LIBOR. They show that the introduction of TAF had been successful, where a cumulative reduction of 50 basis points in the LIBOR-OIS spread can be associated with the TAF announcements and its operations (also see Wu (2008)).

Furthermore, during the crisis, we observed extended maturities and a broader range of collateral accepted by many central banks. William Buiter provides a rationale for this by criticizing Bank of England's approach in the early days of the crisis for its very strict collateral requirements: "Basically, they would discount only stuff that is already liquid: UK government securities; European Economic Area government securities; a few international organizations' debt like the World Bank; and then under special circumstances, US Treasury bonds. All that stuff is liquid already."

\subsection{Moral suasion}

Outside of the scope of our model, but of relevance to its conclusions, is the role of central banks beyond that of LOLR. Much like the constraints of the IMF in dealing with the 80s' LDC debt crisis, in most serious cases of financial crises, central banks do not have sufficient resources to be able to deal with the crisis out of their own funds or expertise to nationalize a large part of the financial sector. Hence, central bank funding in rescue packages is often tied with private-sector funding as well as ownership of rescued institutions, either by a single private player or a consortium. Such quasi-regulatory support operations are likely to be effective only if done with leadership, guidance and moral suasion of a central bank that must impress upon profit-maximizing private players the need to coordinate an outcome that balances their profit objectives with broader welfare concerns.

The crucial feature necessary to allow a central bank to carry out this function is that it should be above the competitive battle, a noncompetitive, non-profit-maximizing body. The success of the Long Term Capital Management (LTCM) rescue in 1998 with a consortium of bankers, and the expedient resolution of Bear Stearns' distress through a sale to J.P.Morgan Chase in March 2008, both at initiatives of the Fed, point to the

aimed to support a private-sector initiative designed to provide liquidity to U.S. money market investors; 8) Term Asset-Backed Securities Loan Facility (TALF) (announced 11/25/2008) - is designed to help market participants meet the credit needs of households and small businesses by supporting the issuance of asset-backed securities (ABS) collateralized by auto loans, student loans, credit card loans etc.

${ }^{23}$ Acharya and Backus (2009) point out, however, that given potential solvency concerns about borrowing banks, such lender of last resort might need to be combined with solvency-linked covenants, as in private lines of credit that banks write for their borrowers. 
importance of this coordination role of central banks.

\section{Conclusion}

We proposed in this paper that during crises and more generally when distribution of liquidity among banks is highly skewed, surplus banks may not lend efficiently to needy banks due to the strategic gains to be made upon the closure of troubled banks or upon the liquidation of their assets. This problem was shown to be more acute the weaker the market for assets outside of the banking sector, a scenario that would arise, for instance, in liquidation of opaque and information-sensitive assets and relationship-specific loans made to small borrowers.

Such strategic behavior describes well crises in the pre-Fed era and provides a rationale for the existence of the central bank. A central bank that is credible in providing liquidity to banks in need at competitive rates, can eliminate the bargaining power of surplus banks in the interbank market and thereby restore the efficiency of liquidity transfers and asset sales. This lender-of-last-resort rationale for the existence of a central bank complements the traditional one pertaining to times of aggregate liquidity shortages and contagious failures. Our model illustrates that the public provision of liquidity can improve its private provision even when aggregate liquidity is in surplus. More broadly, our model also provides a rationale for central banks to play the role of coordinating liquidity injection to needy institutions, if required, through moral suasion.

Our analysis can be extended in several directions. On the modeling front, perhaps one limitation of our model is that the structure of liquidity shocks is exogenous. It would be useful to endogenize this based on the optimal liability structure of banks (Diamond and Rajan (2001), Acharya and Viswanathan (2009)). In particular, how do issues of market power and the resulting under-provision of liquidity insurance affect the optimal asset-liability (mis)match and liquidity management by banks?

Another limitation is that we take the structure of inter-bank relationships and market power as given. Is there market power of some form that arises naturally due to inter-bank relationships that are efficient from an ex-ante perspective. What is the ex-ante industrial organization design that is optimal for inter-bank markets? In particular, does it feature "tiering" where some large banks hoard reserves and acquire rents during crises, and others remain smaller, less liquid players, borrowing from large banks, but get squeezed during crises? Answering these questions in future work remains an important research agenda as analysis of efficient central bank interventions from an ex-ante perspective must be undertaken in such a richer setup.

\section{References}

Acharya, Viral and David Backus (2009), "The Role for Conditionality in the Lender of Last Resort," Chapter 14 in Restoring Financial Stability: How to Repair a Failed 
System, edited by Viral Acharya and Matthew Richardson, John Wiley \& Sons, March 2009.

Acharya, Viral and Ouarda Merrouche (2009), "Precautionary Hoarding of Liquidity and Inter-Bank Markets: Evidence from the Sub-prime Crisis," Working Paper, New York University Stern School of Business.

Acharya, Viral and S. Vishwanathan (2009), "Leverage, Moral Hazard and Liquidity," Working Paper, London Business School.

Acharya, Viral and Tanju Yorulmazer (2008) "Cash-in-the-Market Pricing and Optimal Resolution of Bank Failures", Review of Financial Studies, 21(6), 2008, 2705-42.

Allen, Franklin, and Douglas Gale (2000), "Financial Contagion," Journal of Political Economy, 108, 1-31.

Bagehot, William (1873), Lombard Street: A Description of the Money Market, London: H. S. King.

Bank of England (2005) "Reform of the Bank of England's Operations in the Sterling Money Markets", April.

Bech, Morten and Enghin Atalay (2008), "The Topology of the Federal Funds Market", Federal Reserve Bank of New York Staff Report \#354.

Berger, Allen, Sally Davies, and Mark Flannery (2000), "Comparing Market and Regulatory Assessments of Bank Performance: Who Knows What When?" Journal of Money, Credit and Banking, 32, 641-670.

Bhattacharya, Sudipto, and Douglas Gale (1987), "Preference Shocks, Liquidity and Central Bank Policy," in W. Barnett and K. Singleton, eds., New Approaches to Monetary Economics, Cambridge University Press, 69-88.

Bolton, Patrick, and David S. Scharfstein (1990), "A Theory of Predation Based on Agency Problems in Financial Contracting," American Economic Review, 80, 93106.

Brunnermeier, Markus, and Lasse Pedersen (2005), "Predatory Trading," Journal of Finance, 60(4), 1825-63.

Cai, Fang (2003), "Was There Front Running During the LTCM Crisis?" Federal Reserve Board, International Finance Discussion Paper No. 758.

Calomiris, Charles (1994), "Is the Discount Window Necessary? A Penn-Central Perspective," Federal Reserve Bank of St. Louis Review, May-June, 31-55.

Calomiris, Charles, and Charles Kahn (1996), "The Efficiency of Self-Regulated Payments Systems: Learning from the Suffolk System," Journal of Money, Credit, and Banking, 28, 766-97. 
Carlin, Bruce Ian, Miguel Sousa Lobo, and S. Vishwanathan (2007), "Episodic Liquidity Crisis: Cooperative and Predatory Trading," forthcoming, Journal of Finance.

Cestone, Giacinta (2000), "Corporate Financing and Product Market Competition: An Overview," Giornale degli Economisti e Annali di Economia, 58, 269-300.

Chernow, Ron (1990), The House of Morgan: The Secret History of Money and Power, Simon \& Schuster, Sydney.

Cleveland, van B. Harold, and Thomas F. Huertas (1985), Citibank, 1812-1970, Harvard University Press, Cambridge, Massachusetts.

Cocco, Joao F., Francisco J. Gomes and Nuno C. Martins (2005), "Lending Relationships in the Interbank Market," forthcoming, Journal of Financial Intermediation.

Corrigan, E. G. (1990), Statement before US Senate Committee on Banking, Housing and Urban Affairs, Washington D.C.

Dell'Arricia, Giovanni, Enrica Detragiache and Raghuram Rajan (2008), "The Real Effect of Banking Crises", Journal of Financial Intermediation, 17(1), 89-112.

Diamond, Douglas, and Raghuram Rajan (2001), "Liquidity Risk, Liquidity Creation, and Financial Fragility: A Theory of Banking," Journal of Political Economy, 109(2), 287-327.

Diamond, Douglas, and Raghuram Rajan (2005), "Liquidity Shortages and Banking Crises," Journal of Finance, 60(2), 615-647.

Donaldson, R. Glen (1992), "Costly Liquidation, Interbank Trade, Bank Runs and Panics," Journal of Financial Intermediation, 2, 59-85.

Dunn, Kenneth B., and Chester S. Spatt (1984), "A Strategic Analysis of Sinking Funds Bonds," Journal of Financial Economics, 13, 399-423.

Fama, Eugene (1985), "What's Different About Banks?," Journal of Monetary Economics, 15, 29-39.

Flannery, Mark (1996), "Financial Crises, Payments System Problems and Discount Window Lending," Journal of Money, Credit and Banking, 28, 804-824.

Freixas, Xavier, Curzio Giannini, Glenn Hoggarth, and Farouk Soussa (1999), "Lender of Last Resort: A Review of the Literature," Bank of England Financial Stability Review, 7, 151-167.

Freixas, Xavier, and Cornelia Holthausen (2005) "Interbank Market Integration under Asymmetric Information," Review of Financial Studies, 18, 2, 458-490.

Freixas, Xavier, and Jose Jorge (2007), "The Role of Interbank Markets in Monetary Policy: A Model with Rationing," mimeo, Universitat Pompeu Fabra.

Furfine, Craig (2001) "Banks as Monitors of Other Banks: Evidence from the Overnight Federal Funds Market," Journal of Business, 74, 33-57. 
Goodfriend, M. and R.G. King (1988), "Financial Deregulation, Monetary Policy and Central Banking", Federal Reserve Bank of Richmond Economic Review, Vol. 74, No: 3.

Goodhart, Charles (1969), The New York Money Market and the Finance of Trade, 1900-1913, Cambridge, Mass: Harvard University Press.

Goodhart, Charles (1988), The Evolution of Central Banks, MIT Press, Cambridge, Massachusetts.

Goodhart, Charles, and Dirk Schoenmaker (1995), "Should the Functions of Monetary Policy and Banking Supervision be Separated?," Oxford Economic Papers, 47, 539560 .

Gorton, Gary (1985), "Clearinghouses and the Origin of Central Banking in the United States," Journal of Economic History, 45, 277-283.

Gorton, Gary, and Donald Mullineaux (1987), "The Joint Production of Confidence: Endogenous Regulation and Nineteenth Century Commercial-Bank Clearinghouses," Journal of Money Credit and Banking, 19, 457-468.

Gorton, Gary, and Lixin Huang (2002), "Banking Panics and the Origin of Central Banking," NBER Working Paper No. 9137, Cambridge, MA,US.

Gorton, Gary, and Lixin Huang (2006), "Banking Panics and the Endogeneity of Central Banking," Journal of Monetary Economics, 53, 1613-1629.

Holmström, Bengt, and Jean Tirole (1998), "Private and Public Supply of Liquidity," Journal of Political Economy, 106, 1-40.

Jaffee, Dwight M. (1989), Money, Banking and Credit, Worth Publishers, New York.

James, Christopher M. (1987) "Some Evidence on the Uniqueness of Bank Loans," Journal of Financial Economics, 19, 217-235.

James, Christopher M., and Joel Houston (1996) "Bank Information Monopolies and the Mix of Private and Public Debt Claims," Journal of Finance, 51(5), 1863-1889.

Kindleberger, Charles P. (1978), Manias, Panics, and Crashes: A History of Financial Crises, New York: Basic Books.

Krozner, Randy, Laeven, Luc, Klingebiel, Daniel (2007) "Banking Crises, Financial Dependence, and Growth," Journal of Financial Economics, 84, 187-228.

Lang, Larry H. P., and René Stulz (1992) "Contagion and Competitive Intra-industry Effects of Bankruptcy Announcements," Journal of Financial Economics, 32, 45-60.

Leitner, Yaron (2005), "Financial Networks: Contagion, Commitment, and Private Sector Bailouts," Journal of Finance, 60, 2925-2953. 
McAndrews, James, Asani Sarkar and Zhenyu Wang (2008) "The Effect of the Term Auction Facility on the London Inter-Bank Offered Rate", Federal Reserve Bank of New York Staff Reports \#335, July.

Moen, Jon R. and Ellis W. Tallman (2006), "Liquidity Creation without a Lender of Last Resort: Clearinghouse Loan Certificates in the Banking Panic of 1907," Federal Reserve Bank of Atlanta Working Paper, 2006-23.

Park, Sangkyun (1991) "Bank Failure Contagion in Historical Perspective," Journal of Monetary Economics, 28, 271-286.

Pope, David (1989) "Free Banking in Australia before World War I," Australian National University, Working Papers in Economic History No. 129.

Repullo, Rafael (2005), "Liquidity, Risk Taking, and the Lender of Last Resort," International Journal of Central Banking, 1, 47-80.

Rochet, Jean-Charles, and Jean Tirole (1996), "Interbank Lending and Systemic Risk," Journal of Money, Credit and Banking, 28, 733-762.

Rubinstein, Ariel (1982), "Perfect Equilibrium in a Bargaining Model," Econometrica, 50(1), 97-109.

Saunders, Anthony (1987) "The Interbank Market, Contagion Effects and International Financial Crises," in Threats to International Financial Stability, R. Portes and A. K. Swoboda, eds., New York, NY: Cambridge University Press, 196-232.

Saunders, Anthony, and Berry Wilson (1996), "Contagious Bank Runs: Evidence from the 1929-1933 Period," Journal of Financial Intermediation, 5, 409-423.

Schumacher, Liliana (2000), "Bank Runs and Currency Run in a System without a Safety Net: Argentina and the 'Tequila' Shock," Journal of Monetary Economics, $46,257-277$.

Shleifer, Andrei, and Robert Vishny (1992), "Liquidation Values and Debt Capacity: A Market Equilibrium Approach," Journal of Finance, 47, 1343-1366.

Sinclair, Andrew (1981), Corsair: The Life of J. Pierpont Morgan, Boston and Toronto: Little, Brown.

Slovin, Myron B., Marie E. Sushka, and John A. Polonchek (1999) "An Analysis of Contagion and Competitive Effects at Commercial Banks," Journal of Financial Economics, 54, 197-225.

Sprague, Oliver (1910), History of Banking Crises Under the National Banking System, US Government Printing Office, Washington D.C., US.

Strouse, Jean (1999), Morgan: American Financier, Random House.

Timberlake, R. H., Jr. (1984), "The Central Banking Role of Clearinghouse Associations," Journal of Money, Credit and Banking, 16(1), 1-15. 
Tucker, Paul (2004), "Managing the Central Bank's Balance Sheet: Where Monetary Policy Meets Financial Stability", Lecture to Mark the 15th Anniversary of Lombard Street Research, 28 July.

Wu, Tao (2008), "On the Effectiveness of the Federal Reserves New Liquidity Facilities," Working Paper, Federal Reserve Bank of Dallas. 


\section{Appendix A: Proofs}

Proof of Proposition 1: Setting $r=R-R_{b}$ is weakly optimal since Bank $A$ can always compensate an increase in $r$ with an offsetting increase in $T$. Bank $B$ 's participation constraint is binding since otherwise, Bank $A$ can always increase $T$. Hence, we have:

$$
T=F(\hat{\theta}) p_{H}\left(R-R_{b}\right)+\int_{\hat{\theta}}^{1}\left[p_{B}(\theta) R-\rho\right] d F(\theta)-X_{B}
$$

Substituting, we can write Bank $A$ 's problem as:

$$
\begin{array}{ll}
\max _{\hat{\theta}} & \int_{0}^{\hat{\theta}} p_{H} R d F(\theta)+\int_{\hat{\theta}}^{1} p_{B}(\theta) R d F(\theta)-\rho-X_{B} \\
\text { s.t. } & F(\hat{\theta}) p_{H}\left(R-R_{b}\right)+\int_{\hat{\theta}}^{1}\left[p_{B}(\theta) R-\rho\right] d F(\theta)-X_{B}-F(\hat{\theta}) \rho \geq 0
\end{array}
$$

Since $p_{H}>p_{B}(\theta)$ for all $\theta \in(0,1)$, the objective increases in $\hat{\theta}$. Note that condition $(6)$ the constraint is satisfied for $\hat{\theta}=0$. Moreover, its LHS decreases with $\hat{\theta}$ (Assumption 1 ). If the constraint holds for $\hat{\theta}=1$, i.e., if $p_{H}\left(R-R_{b}\right)-\rho \geq X_{B}$, then $\theta_{A}^{*}=1$. Note that in this outcome, Bank $A$ borrows more than the funds needed to refinance all its loans, i.e., $T_{A}^{*}>\rho$. This outcome is equivalent to (among others) Bank $A$ borrowing exactly $T_{A}^{*}=\rho$ against a debt claim $r_{A}^{*}=\left(X_{B}+\rho\right) / p_{H}$. Otherwise, it is optimal to set $\theta_{A}^{*}$ at the point where it binds, i.e., $T_{A}^{*}=F\left(\theta_{A}^{*}\right) \rho$ and $\theta_{A}^{*}$ is as in (9).

Proof of Proposition 2: Setting $r=R-R_{b}$ is weakly optimal since Bank $B$ can always compensate an increase in $r$ with an offsetting increase in $T$. Since Bank $A$ can always increase $T$, one of the other two constraints must bind. Hence Bank $B$ 's problem can be written as:

$$
\begin{array}{ll}
\max _{\hat{\theta}, T} & \int_{0}^{\hat{\theta}} p_{H}\left(R-R_{b}\right) d F(\theta)+\int_{\hat{\theta}}^{1}\left[p_{B}(\theta) R-\rho\right] d F(\theta)-T \\
\text { s.t. } & T=F(\hat{\theta}) \rho+\max \left\{E\left(\pi_{A}\right)-F(\hat{\theta}) p_{H} R_{b} ; 0\right\} .
\end{array}
$$

If $E\left(\pi_{A}\right)>F(\hat{\theta}) p_{H} R_{b}$, the objective becomes:

$$
\int_{0}^{\hat{\theta}} p_{H} R d F(\theta)+\int_{\hat{\theta}}^{1} p_{B}(\theta) R d F(\theta)-\rho-E\left(\pi_{A}\right)
$$

which increases with $\hat{\theta}$, i.e., $F^{\prime}(\hat{\theta})\left(p_{H} R-p_{B}(\hat{\theta}) R\right)>0$.

If $E\left(\pi_{A}\right) \geq F(\hat{\theta}) p_{H} R_{b}$ for $\hat{\theta}=1$, i.e., if $E\left(\pi_{A}\right) \geq p_{H} R_{b}$, then $\theta^{*}=1$. This implies $T^{*}=\rho+E\left(\pi_{A}\right)-p_{H} R_{b}$. Note that in this outcome, Bank $A$ borrows more than the funds needed to refinance all its loans, i.e., $T^{*}>\rho$. This outcome is equivalent to (among others) Bank $A$ borrowing $T^{*}=\rho$ against a debt claim $r^{*}=R-E\left(\pi_{A}\right) / p_{H}$. 

is:

If $E\left(\pi_{A}\right)<p_{H} R_{b}$, it may be that $E\left(\pi_{A}\right)<F(\hat{\theta}) p_{H} R_{b}$, in which case the objective

$$
\int_{0}^{\hat{\theta}} p_{H}\left(R-R_{b}\right) d F(\theta)+\int_{\hat{\theta}}^{1} p_{B}(\theta) R d F(\theta)-\rho .
$$

From Assumption 1, this objective decreases with $\hat{\theta}$, i.e., $F^{\prime}(\hat{\theta})\left(p_{H}\left(R-R_{b}\right)-p_{B}(\hat{\theta}) R\right)<$ 0 . In that case, $\theta^{*}$ such that $E\left(\pi_{A}\right)=F\left(\theta^{*}\right) p_{H} R_{b}$ is optimal.

Proof of Corollary 1: $\alpha^{*}=0$ if and only if $E\left(\pi_{A}\right) \geq p_{H} R_{b}$. Expressions (6) and (9) imply $\pi_{A}>X_{A}$. Hence, $\partial E\left(\pi_{A}\right) / \partial \beta<0$. The condition holds for $\beta=0$ if

$$
p_{H}\left(R-R_{b}\right)-\rho \geq X_{B},
$$

and is violated for $\beta=1$ if $\theta^{*}<1$, i.e., if

$$
p_{H} R_{b}>X_{A} .
$$

Note that under (6), (30) and/or (31) must hold. When both hold, $\beta^{*} \in(0,1)$. When only (30) holds, $\beta^{*}=1$. When only (31) holds, $\beta^{*}=0$. For $\beta>\beta^{*}, \theta^{*}=F^{-1}\left(E\left(\pi_{A}\right) / p_{H} R_{b}\right)$ which is strictly decreasing with $E\left(\pi_{A}\right)$ which is itself strictly decreasing with $\beta$.

Proof of Corollary 2: For $\beta^{*} \in(0,1)$, the threshold $\beta^{*}$ is given by $E\left(\pi_{A}\right)=p_{H} R_{b}$ with $E\left(\pi_{A}\right)=\beta \pi_{A}+(1-\beta) X_{A}$ and $\pi_{A}=p_{H} R_{b} F\left(\theta_{A}^{*}\right)$. Therefore

$$
\beta^{*}=\min \left\{1 ; \max \left\{0 ; 1-\frac{p_{H} R_{b}-X_{A}}{p_{H} R_{b} F\left(\theta_{A}^{*}\right)-X_{A}}\right\}\right\} .
$$

By inspection $\partial \beta^{*} / \partial X_{A}<0$. For $\beta^{*} \in(0,1)$, the derivative w.r.t. $X_{B}$ of the denominator $D$ is

$$
\frac{\partial D}{\partial X_{B}}=\left(\frac{\partial \theta_{A}^{*}}{\partial X_{B}}\right)\left(\frac{\partial D}{\partial \theta_{A}^{*}}\right)=-\left(\frac{\partial \theta_{A}^{*}}{\partial X_{B}}\right) p_{H} R_{b} F^{\prime}\left(\theta_{A}^{*}\right)>0 .
$$

Similarly, if $\beta>\beta^{*}$, we have $E\left(\pi_{A}\right)=p_{H} R_{b} F\left(\theta^{*}\right)$ which can be rewritten as

$$
p_{H} R_{b} F\left(\theta^{*}\right)=\beta X_{A}+(1-\beta) p_{H} R_{b} F\left(\theta_{A}^{*}\right) .
$$

The LHS increases with $\theta^{*}$ while we have

$$
\begin{aligned}
& \frac{\partial R H S}{\partial X_{A}}=\beta>0 \quad \frac{\partial R H S}{\partial \theta_{A}^{*}}=(1-\beta) p_{H} R_{b} F^{\prime}\left(\theta_{A}^{*}\right)>0 \\
& \frac{\partial R H S}{\partial \rho}=\left(\frac{\partial R H S}{\partial \theta_{A}^{*}}\right)\left(\frac{\partial \theta_{A}^{*}}{\partial \rho}\right)<0 \quad \frac{\partial R H S}{\partial X_{B}}=\left(\frac{\partial R H S}{\partial \theta_{A}^{*}}\right)\left(\frac{\partial \theta_{A}^{*}}{\partial X_{B}}\right)<0
\end{aligned}
$$

These together with $\frac{\partial \alpha^{*}}{\partial \theta^{*}}<0$ and $\frac{\partial K^{*}}{\partial \theta^{*}}<0$ complete the proof.

Proof of Proposition 3: For $\beta>\beta^{*}$, we must be in the second case of Lemma 1. Consider first the effect of $b_{o}$. In the second case, we have

$$
\frac{\partial \theta_{o}^{*}}{\partial R_{o}^{b}}=\frac{p_{H} F\left(\theta_{o}^{*}\right)}{-\left(p_{o}(\theta) R-p_{H}\left(R-R_{b}^{o}\right)\right)}
$$


which is negative since $\theta_{o}^{*}$ is the largest solution to (16). Moreover,

$$
\frac{\partial X_{A}}{\partial \theta_{o}^{*}}=\left(p_{H}-p_{o}\left(\theta_{o}^{*}\right)\right) R F^{\prime}\left(\theta_{o}^{*}\right)>0
$$

Hence $\frac{\partial X_{A}}{\partial R_{o}^{b}}<0$, implying $\frac{\partial X_{A}}{\partial b_{o}}<0$. The implications for $\alpha^{*}$ and $K^{*}$ are an application of Corollary 2 .

Proof of Proposition 7: Consider state $\omega=(\rho, 1)$. Following the transfer $T(\omega)$, Bank $A$ can refinance a fraction $T(\omega) / \rho$ of its loans and therefore, its expected payoff is $\pi_{A}(\omega)=p_{H}(R-r(\omega)) \frac{T(\omega)}{\rho}$. Hence Bank $B$ 's best renegotiation offer ensures Bank $A$ that same payoff, minimizing the fraction $\alpha^{\prime}$ of loans sold to Bank $B$, i.e., $\left(1-\alpha^{\prime}\right) p_{H} R_{b}=$ $\pi_{A}(\omega)$. (Note that since $r(\omega) \leq R-R_{b}$, we have $\left(1-\alpha^{\prime}\right) \geq \frac{T(\omega)}{\rho}$, i.e., Bank $B$ does not decrease its transfer to Bank A.) Therefore, Bank $B$ 's expected payoff is

$$
\begin{aligned}
\pi_{B}(\omega) & =\alpha^{\prime} p_{B} R+\left(1-\alpha^{\prime}\right) p_{H}\left(R-R_{b}\right)-\rho \\
& =\left(1-\frac{(R-r(\omega)) T(\omega)}{R_{b} \rho}\right) p_{B} R+\frac{(R-r(\omega)) T(\omega)}{R_{b} \rho} p_{H}\left(R-R_{b}\right)-\rho
\end{aligned}
$$

Consider state $\omega=(\rho, \mu)$. As before, Bank $A$ 's expected payoff is $\pi_{A}(\omega)=p_{H}(R-r(\omega)) \frac{T(\omega)}{\rho}$. Bank $B$ 's best renegotiation offer ensures Bank $A$ that same payoff, minimizing the transfer $T^{\prime}$, which amounts to minimizing the fraction $\left(1-\alpha^{\prime}\right)$ of loans retained by Bank $A$, i.e., $\left(1-\alpha^{\prime}\right) p_{H} R=\pi_{A}(\omega)$. (Note that since $r(\omega) \geq 0$, we have $\left(1-\alpha^{\prime}\right) \leq \frac{T(\omega)}{\rho}$, i.e., Bank $B$ does not increase its transfer to Bank $A$.) Therefore, Bank $B$ 's expected payoff is

$$
\pi_{B}(\omega)=-\left(1-\alpha^{\prime}\right) \rho \mu=-\frac{(R-r(\omega)) T(\omega)}{R_{b}} \mu
$$

Consider state $\omega=(0,1)$. It is easily seen that the maximum expected payoff the contract can ensure in this state without asset sales is $\pi_{B}(\omega)=p_{H}\left(R-R_{b}\right)$.

If there is no contract at $t=0$, Bank $B$ 's payoff is zero in all states except $\omega=(\rho, 1)$ in which it can acquire all of Bank $A$ 's assets for no transfer and refinance them, so that its expected payoff is $\pi_{B}=x(1-y)\left(p_{B} R-\rho\right)$.

The optimal contract chosen by Bank $A$ at $t=0$ maximizes $T(\rho)$ subject to

$$
(1-x) \pi_{B}(0,1)+x(1-y) \pi_{B}(\rho, 1)+x y \pi_{B}(\rho, \mu) \geq \pi_{B} .
$$

This can be rewritten as

$$
T(\rho) \leq \frac{(1-x) p_{H}\left(R-R_{b}\right) \rho}{x(R-r(\rho))\left[(1-y) \frac{p_{B} R-p_{H}\left(R-R_{b}\right)}{R_{b}}+y \frac{\mu}{R} \rho\right]}
$$

The constraint is relaxed when $r(\rho)$ is maximized. Therefore it is optimal to set $r(\rho)=$ $\left(R-R_{b}\right)$. Given this, the constraint can be rewritten as $T(\rho) \leq T^{*}$ with $T^{*}$ as in $(22)$ 


\section{Appendix B: Historical and current evidence}

This section discusses some of the private arrangements amongst banks to manage liquidity shocks before the modern central banking era, as well as the role of strategic behavior in their failure, as witnessed during significant historical episodes (see Freixas et al. (1999) for a survey).

\section{I) The failure of private coinsurance arrangements}

Orchestrated liquidity support operations occurred often in the past. In the US, the Clearinghouse System assumed a crisis prevention and management role before the establishment of the Federal Reserve System in December 1913 (e.g. Gorton (1985), Gorton and Mullineaux (1987), Calomiris and Kahn (1996), Gorton and Huang (2002, 2006)). The first clearinghouse, established by the New York City banks in 1853, created an organized market for exchange between banks. During normal times, clearinghouses performed their service of clearing payments, whereas during crisis periods, they evolved into an organization that managed the crisis by helping member banks sustain their solvency and liquidity positions. During such periods, clearinghouses used several methods such as suspension of payments, equalization of reserves and issuance of clearinghouse loan certificates to ease the suffering of the member banks in distress. The equalization of reserves, essentially the pooling of all legal reserves of clearinghouse member banks in an emergency and granting member banks equal access to that pool, eased the liquidity constraint on banks experiencing runs. Also, clearinghouses issued loan certificates that were acquired by banks by depositing qualifying assets with the Clearing House Association to be used in interbank settlements. These loan certificates prevented costly asset liquidations and improved affected banks' liquidity position. Since they were provided only when the Clearing House Association decided that the bank had enough assets to back them up, loan certificates also served the purpose of certifying that the bank was healthy (Park (1991)).

Such private arrangements and voluntary participation into efforts to help distressed banks worked well at times. However, their effectiveness was hampered by competitive pressures in the banking industry. In particular, voluntary participation was often difficult to elicit due to the short-term competitive advantage healthy banks could enjoy during crises. The Clearinghouse System was eventually brought down early in the 20th century by the sharp increase in banking competition in New York.

\section{II) 1907 panic in the US}

We now discuss the 1907 panic in the US, a salient example in which the private rescue of distressed banks was hampered by competitive behavior among banks.

i) The role of J.P.Morgan: Sprague (1910)'s discussion of the 1907 panic in New York suggests that the banks' initial reluctance to organize a private rescue of distressed trust companies might have lain in the fact that other banks were not adversely affected by trust companies' difficulties or even benefited by attracting their depositors. 
The immediate cause of the panic was the collapse of copper stocks. On October 17, depositors started running on the Mercantile National Bank. The bank's president, Heinze, had tried to corner the stock of United Cooper. Runs spread to banks controlled by Morse and Thomas, two speculators financially affiliated with Heinze. The New York Clearing House Association granted assistance to those banks after examining their solvency and forcing Heinze, Morse and Thomas to resign. This action subdued severe runs on banks.

Trust companies, however, were also experiencing difficulties. Depositors, suspicious about their involvement in speculation, started running on the Knickerbocker Trust Company on October 21 and on the Trust Company of America on October 23. The New York Clearing House, an organization of banks, did not extend assistance to the trust companies. The Knickerbocker was forced to suspend on October 22, and the Trust Company of America, a solvent institution, had to suffer runs for two weeks. Eventually, US Secretary of the Treasury George B. Cortelyou earmarked $\$ 35$ million of Federal money to quell the storm. On November 6, New York trust companies, urged by J.P. Morgan, organized a team of bank and trust executives, redirected money between banks, secured further international lines of credit, and bought plummeting stocks of healthy corporations. ${ }^{24}$ In particular, they raised a $\$ 25$ million fund for distressed trust companies and required the Trust Company of America to deposit its shares and assets with a committee of trust company presidents. Runs on the Trust Company of America and other small institutions subsided after the resolution.

While J.P.Morgan is credited as having played the role of coordinator and rescuer of this financial crisis, several aspects of his involvement suggest strategic behavior and market power.

First, in 1906 Heinze had acquired Knickerbocker Trust and Morse gained control of the Bank of North America. Even prior to the 1907 crisis, banking industry leaders, one being J.P.Morgan, staged a financial attack on Heinze's Knickerbocker Trust. They felt threatened by the developing trusts and wished to sway public and congressional opinion against them.

Second, the banks controlled by Morgan and his associates experienced only minor difficulties in 1907 thanks to their reputation for soundness. According to Sprague (1910, pages 262-265), while five banks controlled by Heinze and Morse suffered severe deposit withdrawals, the six strongest clearinghouse banks showed slight gains in deposits. The delay in leading assistance to the trust companies is thus often perceived to be strategic on part of the clearinghouse banks.

Third, and most important, Chernow (1990) discusses how J.P. Morgan benefited from trust companies' difficulties during the 1907 crisis (see pages 126-128). On November 2, Morgan (finally) organized a rescue package for the distressed Trust Company of America, Lincoln Trust, and Moore and Schley. Moore and Schley, a speculative brokerage house that was $\$ 25$ million in debt, held a big majority stake in the Tennessee Coal and Iron

\footnotetext{
${ }^{24}$ Moen and Tallman (2006) confirm that the large New York banks acted as private liquidity providers using New York Clearing House loan certificates and that this led to difficulties in the distribution of liquidity.
} 
Company as collateral against loans. If Moore and Schley had to liquidate that stake, it might collapse the stock market, and Moore and Schley's collapse might in turn pull down other institutions. To save Moore and Schley, Morgan wanted some benefit for himself and told friends he had done enough and wanted some quid pro quo. He arranged a deal where US Steel, his favorite creation that could profit from Tennessee Coal's huge iron ore and coal holdings in Tennessee, Alabama and Georgia, would buy Tennessee Coal stock from Moore and Schley if trust company presidents assembled a $\$ 25$ million pool to protect weaker trusts. While the takeover would normally have been impossible for antitrust reasons, US Steel managed to secure President Roosevelt's approval and the Sherman Antitrust Act was not be used against it. Senator La Follette said bankers had rigged up the panic for their own profit. Financial analyst John Moody said that the Tennessee Coal and Iron's property had a potential value of about $\$ 1$ billion, which confirmed the $\$ 45$ million distressed price being a steal. ${ }^{25}$ Later on, Grant B. Schley, head of Moore and Schley, admitted that his firm could have been rescued by an outright cash infusion rather than the sale of the Tennessee Coal stock.

The 1907 crisis paved the way for the establishment of the Federal Reserve System as Senator Aldrich declared: "Something has got to be done. We may not always have Pierpont Morgan with us to meet a banking crisis" (Sinclair (1981)). ${ }^{26}$ The Fed was a natural response to the realization that control and leadership of the US financial system had effectively been outsourced to one private businessman.

ii) Cash hoarding by Citibank: Cleveland and Huertas (1985) discuss the 1893 and 1907 crises and specifically the strategy of the National City Bank (which was to become Citibank) to anticipate crises and to build up liquidity and capital beforehand to benefit from the difficulties of its competitors. About the 1907 crisis, they write (page 52):

National City Bank again emerged from the panic a larger and stronger institution. At the start, National City had higher reserve and capital ratios than its competitors, and during the panic it gained in deposits and loans relative to its competitors. Stillman (President) had anticipated and planned for this result. In response to Vanderlip's (Vice President) complaint in early 1907 that National City's low leverage and high reserve ratio was depressing profitability, Stillman replied: "I have felt for sometime that the next panic and low interest rates following would straighten out good many things that have of late years crept into banking. What impresses me as most important is to go into next Autumn (usually a time of financial stringency) ridiculously strong and liquid, and now is the time to begin and shape for it... If by able and judicious management we have money to help our dealers when trust companies have suspended, we will have all the business we want for many years." ${ }^{27}$

\footnotetext{
${ }^{25}$ While it is hard to assess the true fundamental value, we report from the discussion of this episode from the book House of Morgan by Ron Chernow (1990), page 128

${ }^{26}$ Strouse (1999) details how during the crisis, panicked crowds on the streets of Manhattan would stop to cheer as J.P.Morgan walked past, puffing at a cigar. So powerful was the House of Morgan - more powerful in the financial world than the government - that nobody dared say no to him. The 1907 crisis was played out in his library amid his collection of books and art. Dozens of financiers would be in the room as Morgan told them they had to work collectively. At one point he locked the doors, refusing to let anyone leave until he had the answer he wanted - at $4 \mathrm{am}$.

${ }^{27}$ Competitive gains to banks from failures of peers are evident in modern times as well: see Saunders
} 


\section{III) Evidence from other countries}

Other historical episodes seem to confirm a tension exists between the viability of private arrangements and competition. An important example is the 1893 financial crisis in Australia. The Australian banking system, which was relatively unregulated during the second half of the 19th century with no central bank and no government-provided deposit insurance, entered a crisis in 1893, when eleven commercial banks failed and the rest experienced severe runs. At the time, the Associated Banks of Victoria was a coalition of private banks, just like the Clearing House Association in New York, and had been initially set up to coordinate and divide the finances of the colonial governments. Before the crisis, the Associated Banks announced that, if and when the occasion arose, they would provide financial assistance to each other (The Economist, 3/25/1893, page 364). However, during the crisis, this arrangement proved ineffective when Federal Bank was allowed to fail without any assistance in January 1893. Pope (1989) suggests that competitive pressures played a major role in the failure of private arrangements as banks stood to gain from other banks' failures through increased market shares.

\section{IV) Emergence of modern central banking}

It is important to distinguish two possible reasons for the failure of private coinsurance arrangements: lack of coordination among clearinghouse members (e.g., due to free-riding $)^{28}$ and strategic behavior. It appears that the coordination aspect was factored into the organization of clearinghouses and that it was really market power that led to their failure.

Timberlake (1984) argues that in US clearinghouses one bank usually assumed the central administration role for clearing the other member banks' accounts. However, the fact that the central commercial banks were also competitors had a significant effect on the failure of these private arrangements. In particular, a temptation for the central commercial banks to take the opportunity of a crisis to force a rival out of business by not providing the loans/assistance that a correspondent could have expected in normal times. This concern accords well with the case of J.P.Morgan's role in 1907 crisis. Hence, such conflicts of interest create a natural need for a non-competitive, non-profit maximizing central bank.

Interestingly, early central banks did not take this non-competitive form. In the first half of the 19th century, the key feature of a central bank resided in its relationship with the government and its privileged role as a (monopolistic) note issuer. Importantly, a central bank was considered to be one of the competitive banks. True central banking did not develop until the need for the central banks to be noncompetitive had become realized and established. Bagehot (1873, chapter 7), Goodhart (1985) and Goodhart and Schoenmaker (1995) report episodes of commercial rivalry between central banks and

(1987) on the 1984 failure of Continental Illinois, Saunders and Wilson (1996) on flight to quality of depositors during the Depression era, Slovin, Sushka and Polonchek (1999) on many bank regulatory actions over 1975-92, Schumacher (2000) also on depositors' flight to quality during the 1994-95 Argentinian crisis, among others. Several of these papers also find evidence of contagion (Lang and Stulz (1992)).

${ }^{28}$ Kindleberger (1978), Corrigan (1990), and Goodhart and Schoenmaker (1995) allude to such a possibility. 
needy (regular) banks. We summarize some of these below.

Bagehot wrote his famous Lombard Street in 1873 in the aftermath of the Overend Gurney crash of 1866 when there was suspicion that the unwillingness of the Bank of England, then a private commercial bank, to support that House was due to commercial rivalry. Discussing this episode, Bagehot points out that while it was accepted that the central bank should only assist banks which could expect to be solvent or to regain solvency under normal conditions, a central bank should seek to act for the public good, and not simply as a business competitor. In contrast, the Bank of England's coordination of the rescue of Baring Brothers in 1890, its organization of a "life-boat" during the secondary banking crisis in the early 1970s, and its rescue of Johnson Matthey Bankers Ltd. in 1984 in response to heightened competition in the financial sector (Capie et al. (1994)) are prominent examples of the Bank performing its role in a non-competitive fashion.

The relation between Banque de France and potential competitors in the mid-19th century is another good example. In particular, Banque de France used its influence to restrict competition from chartered banks. Because of such strong influence, the Conseil d'Etat was reluctant to grant charters to banks. And in 1867, after being involved in unsuccessful real estate speculation, Credit Mobilier experienced difficulties and its enemies at Banque de France took advantage of the situation and forced it into liquidation.

These episodes suggest that while competition issues were not central banks' sole raison d'être, their modern form - non-competitive, non-profit maximizing institutions does find its roots in these issues.

\section{V) Interest-rate behavior during crises in pre- and post-Federal Reserve era}

Using US data over 1873-1933, Donaldson (1992) shows that interest rates increased and stock prices plunged during banking panics. He shows that during panics interest rates were substantially larger than before crisis (by as much as $500 \%$ at times!) and extremely volatile, which he interprets as evidence of the market power by surplus banks. He shows that in contrast to the pre-Fed episode, interest rates during crises after the establishment of the Federal Reserve System were not significantly different from the rates before the crises.

Donaldson also tests whether there was a structural change in the pricing of cash between panic and non-panic periods. This would be consistent with the thesis that surplus banks may have used their market power to exploit the difficulties of needy banks during crises. He divides the sample into the pre-Fed (1867-1913) and post-Fed (1914-33) periods, and confirms that cash was indeed priced during panics at higher than non-panic rates in the pre-Fed period whereas this was not so in the post-Fed period (Donaldson (1992), Table 2). ${ }^{29}$ He concludes that the establishment of the Fed to act as a lender-oflast-resort during panic periods prevented surplus banks from exerting market power and

\footnotetext{
${ }^{29}$ The 1914 panic took place in August. The Federal Reserve System was created via the Federal Act of 23/12/1913 and the Reserve Banks opened for business on 16/11/1914. These dates imply that the 1914 panic took place before the Fed was open. Donaldson (1992), Table 1, covers the behavior of interest rates between weeks 31-49 of 1914. A careful examination reveals that the interest rates for 1914 are (slightly) higher than the rates in 1933, which is still consistent with Donaldson's overall argument.
} 
exploiting needy banks.

\section{VI) Market power around recent hedge-fund failures}

In the last ten years, two major hedge funds have collapsed: LTCM in 1998 and Amaranth in 2006. In both cases, other players in markets seem to have tried to exploit the funds' difficulties. We discuss both episodes together with some recent studies of such strategic behavior.

After its remarkable success over 1994-97, LTCM began to experience difficulties during the financial turmoil triggered by the Russian default in August 1998. During the crisis, LTCM had to buy large amounts of Treasury bond futures to unwind its short position. Anticipating the direction of LTCM's trades and with the advantage of being able to observe customer order flow, market makers had incentives to engage in front running, i.e., trading in the same direction knowing that the order will be coming and unwinding the position afterwards to profit from the order's price impact.

For example, Business Week wrote: "...if lenders know that a hedge fund needs to sell something quickly, they will sell the same asset, driving the price down even faster. Goldman Sachs \& Co. and other counterparties to LTCM did exactly that in 1998." 30 Cai (2003) examines the trading behavior of market makers in the Treasury bond futures market when LTCM faced binding margin constraints in 1998 and finds that during the crisis market makers in the aggregate engaged in front running against customer orders from a particular clearing firm (coded PI7) that closely match features of LTCM's trades through Bear Stearns. Furthermore, a significant percentage of market makers made abnormal profits on most trading days during the crisis.

Eventually, fearing that LTCM's fall might lead to costly disruptions in the financial markets, the New York Fed hosted a meeting of fourteen financial institutions that led to a private sector recapitalization of LTCM, which relaxed LTCM's constraints and helped avoid fire sales. This, in turn, reversed the profitability of speculative trading against LTCM.

Similarly, the Wall Street Journal reported Amaranth LLC's failure and the efforts of other energy market players to benefit from its difficulties. ${ }^{31}$ When the risky bets Amaranth had taken in the energy market turned out to be unfavorable, it started to lose value and by the end of Friday, September 15, 2006, was down more than $\$ 2$ billion from its August value. The losses prompted J.P. Morgan, Amaranth's natural-gas clearing broker, to raise margin calls to be paid by Monday, September 18. In the past, Amaranth had met such demands by selling non-energy investments but thinking that some of these could not be liquidated quickly, Amaranth started negotiations with Wall Street banks to raise cash. After lengthy negotiations, Amaranth secured a deal with Goldman Sachs that would require it to pay nearly $\$ 1.85$ billion to take toxic trades off its hands. Amaranth intended to use the $\$ 1$ billion to $\$ 2$ billion in cash J.P. Morgan held in a margin account, to pay Goldman Sachs for the deal. However, J.P. Morgan refused to release Amaranth's cash collateral claiming the deal did not free it from the risk that Amaranth's trades may

\footnotetext{
${ }^{30}$ Business Week, 2/26/2001, "The Wrong Way to Regulate Hedge Funds."

${ }^{31}$ Wall Street Journal, 1/30/2007, "Amid Amaranth's Crisis, Other Players Profited."
} 
not get paid. This killed the deal.

Later on, J.P. Morgan got into the game and agreed to jointly assume most of Amaranth's energy positions with a partner, Citadel Investment Group. Amaranth's total payments to Merrill Lynch, J.P. Morgan and Citadel, plus the last few days' market losses, came to about $\$ 3.2$ billion. While Amaranth suffered huge losses during the process, J.P. Morgan earned an estimated $\$ 725$ million from the deal. In a speech in November 2006 , Mr. Dimon, J.P. Morgan's CEO, said the Amaranth deal produced a "very nice increment to fixed-income trading" and in January 2007, RISK magazine named J.P. Morgan "Energy Derivatives House of the Year."

These two episodes illustrate that market for liquidity transfers are often ridden by strategic behavior by counterparties and lenders, even in the broader landscape of financial institutions (not just banks), especially when the stakes are high.

Some recent papers model such strategic behavior. In Brunnermeier and Pedersen (2005), traders exploit the difficulties of other traders facing forced liquidations. If a distressed large investor must unwind her position, other traders initially trade in the same direction, and, to benefit from the price impact, buy back the same asset. Hence, as in our model, market participants withdraw liquidity, instead of providing it when liquidity is most needed. Similarly, Carlin et al. (2007) analyze the breakdown in cooperation between traders, which manifests itself in predatory trading leading to a liquidity crunch in the market. In their model, traders cooperate most of the time due to their repeated interaction and provide liquidity to each other. However, cooperation can break down, especially when the stakes are high, which leads to predatory trading. While our paper has similarities with these studies, our model is not exclusively about predatory trading or the break-down of implicit contracts. It is instead about the ability to exploit market power in one market (interbank lending market) to benefit in other markets (market for asset sales and product market). 


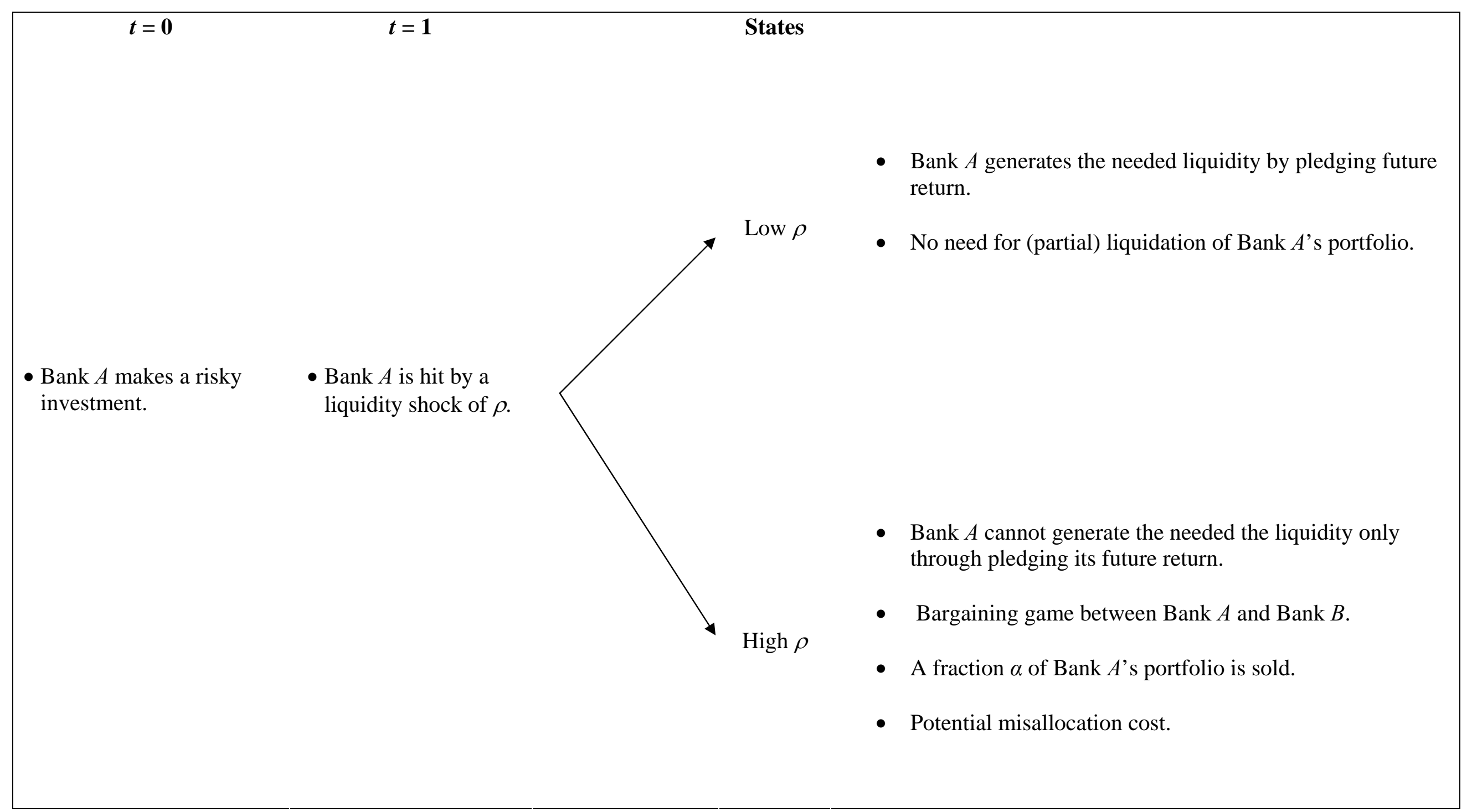

Figure 1: Timeline of the model. 


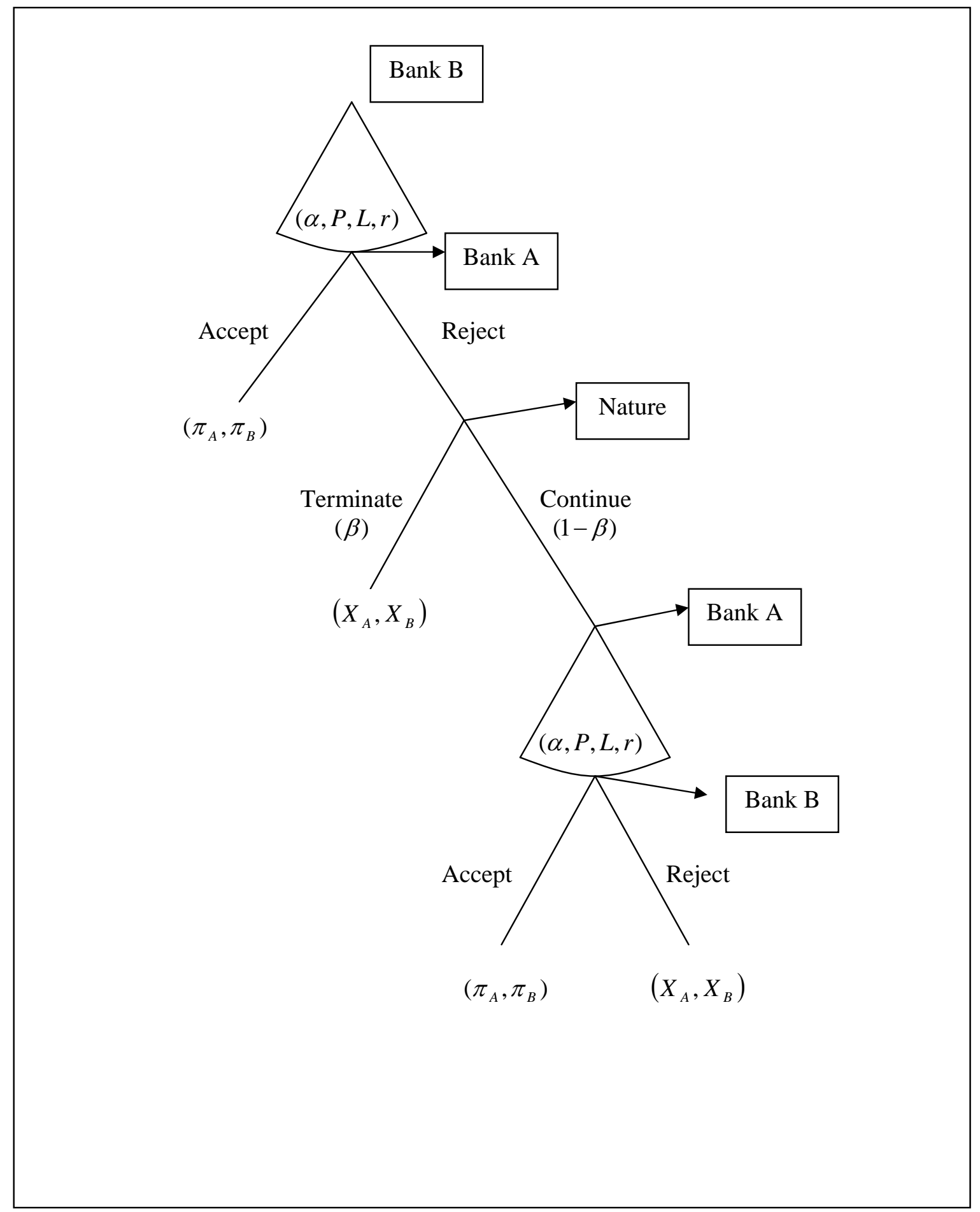

Figure 2: Game tree for the bargaining game. 